\title{
Article \\ A Comprehensive Framework for Standardising System Boundary Definition in Life Cycle Energy Assessments
}

\author{
Hossein Omrany *(D), Veronica Soebarto ${ }^{D}$, Jian Zuo and Ruidong Chang \\ School of Architecture \& Built Environment, University of Adelaide, Adelaide 5005, Australia; \\ veronica.soebarto@adelaide.edu.au (V.S.); jian.zuo@adelaide.edu.au (J.Z.); ruidong.chang@adelaide.edu.au (R.C.) \\ * Correspondence: Hossein.omrany@adelaide.edu.au
}

check for updates

Citation: Omrany, H.; Soebarto, V.; Zuo, J.; Chang, R. A Comprehensive Framework for Standardising System Boundary Definition in Life Cycle Energy Assessments. Buildings 2021, 11, 230. https://doi.org/10.3390/ buildings 11060230

Academic Editor: Umberto Berard

Received: 19 April 2021

Accepted: 25 May 2021

Published: 28 May 2021

Publisher's Note: MDPI stays neutral with regard to jurisdictional claims in published maps and institutional affiliations.

Copyright: (c) 2021 by the authors. Licensee MDPI, Basel, Switzerland. This article is an open access article distributed under the terms and conditions of the Creative Commons Attribution (CC BY) license (https:// creativecommons.org/licenses/by/ $4.0 /)$.

\begin{abstract}
This paper aims to propose a comprehensive framework for a clear description of system boundary conditions in life cycle energy assessment (LCEA) analysis in order to promote the incorporation of embodied energy impacts into building energy-efficiency regulations (BEERs). The proposed framework was developed based on an extensive review of 66 studies representing 243 case studies in over 15 countries. The framework consists of six distinctive dimensions, i.e., temporal, physical, methodological, hypothetical, spatial, and functional. These dimensions encapsulate 15 components collectively. The proposed framework possesses two key characteristics; first, its application facilitates defining the conditions of a system boundary within a transparent context. This consequently leads to increasing reliability of obtained LCEA results for decision-making purposes since any particular conditions (e.g., truncation or assumption) considered in establishing the boundaries of a system under study can be revealed. Second, the use of a framework can also provide a meaningful basis for cross comparing cases within a global context. This characteristic can further result in identifying best practices for the design of buildings with low life cycle energy use performance. Furthermore, this paper applies the proposed framework to analyse the LCEA performance of a case study in Adelaide, Australia. Thereafter, the framework is utilised to cross compare the achieved LCEA results with a case study retrieved from literature in order to demonstrate the framework's capacity for cross comparison. The results indicate the capability of the framework for maintaining transparency in establishing a system boundary in an LCEA analysis, as well as a standardised basis for cross comparing cases. This study also offers recommendations for policy makers in the building sector to incorporate embodied energy into BEERs.
\end{abstract}

Keywords: embodied energy; operational energy; net-zero energy building; energy efficiency; conceptual framework

\section{Introduction}

High-performance buildings have gained momentum over the recent decades owing to their capacity to curb dependency on fossil fuels [1-4]. These buildings are principally constructed to minimise annual operational energy use so that they can achieve net-zero energy (and carbon) usage by integrating on-site renewable or decarbonised energy systems with the buildings [5]. Thus far, this concept has been introduced into the built environment through two general approaches [1]. The first approach is mainly voluntary, aiming to realise highly energy-efficient buildings by embracing green certification programs. Examples of this approach include Passivhaus in Germany [6], green buildings in Australia [7], and Minergie standard in Switzerland [8]. The second approach is a gradual process by which the performance thresholds to achieve energy-efficient buildings (e.g., nearly-zero energy buildings (NZEBs) or net-zero energy buildings) are progressively increased over time through mandatory building codes. In this approach, building energy-efficiency regulations (BEERs) play a vital role in fulfilling the attainment of high-performance buildings. An example of this approach is the Australian energy-efficiency regulations that 
aim to achieve zero energy (and carbon)-ready buildings by 2030 through increasing the mandatory thermal performance requirements for new buildings [9].

Nevertheless, previous studies have shown that the implementation of BEERs may lead to increasing the total environmental impacts of buildings due to their limited scopes to account for the impacts of embodied energy [10-12]. For instance, Omrany et al. [12] analysed the effects of enhancing a building's thermal efficiency on embodied energy. To carry out the study, the thermal performance of a residential building constructed in accordance with minimum mandatory requirements of Australia (i.e., 6-star building) was gradually increased to achieve high-performing buildings. The results showed that the share of embodied energy in total life cycle energy consumption increased from $20-40 \%$ to $50-75 \%$ in transitioning from a standard 6-star building to a highly energy-efficient building. In another study, Stephan et al. [10] analysed the total life cycle energy performance of a passive house located in Belgium and realised that the building's embodied energy constituted up to $77 \%$ of the total life cycle energy consumption. It was conclusively stated that the adoption of current energy-efficiency regulatory schemes may not necessarily result in minimising the overall life cycle energy use of buildings owing to the exclusion of embodied energy.

In recent years, literature has witnessed a growing body of research developed to demonstrate the significance of embodied energy attributed to buildings with high energyefficiency performance. However, this surge of research has been unable to alter the mindset of policy makers about the necessity of abating buildings' embodied impacts when planning for enhancement of sustainability in the built environment [13]. Many studies have attempted to encourage the incorporation of embodied energy into BEERs by increasing the accuracy of embodied energy calculation methods [14-17]; investigating challenges for inclusion of embodied energy into BEERs from the perspectives of building professionals [18,19]; or integrating building information modelling techniques with the life cycle assessment (LCA) approach and building codes [20,21]. Despite increasing attention, the pathway for including the impacts of embodied energy into BEERs is still ambiguous. The chief reason for such an ambiguity resides with the complexity that BEERs encounter in accounting for the impacts of both operational and embodied energies due to various processes and parameters involved.

To address this challenge, the development of a comprehensive framework for a clear description of system boundaries can pave the way towards integrating the life cycle embodied environmental impacts into BEERs. Currently, the literature is lacking such a comprehensive framework. This lack is reflected in the findings of recent studies that reported variations in the results of life cycle energy assessment (LCEA) analyses [22-26]. In a recent study, Pan and Teng [26] conducted a holistic literature review analysis of 244 case studies, aiming to quantify potential variations in embodied energy calculations. The results showed that significant variations may stem from the choice of method for embodied energy assessment, i.e., a $200 \%$ increase from process-based to hybrid method. In addition, the varied approaches of studies to account for the effects of parameters influencing the assessments of embodied and operational energy can be critical in varying LCEA results [23,24]. For instance, Pan and Teng [26] found that unclear descriptions of system boundaries for including cradle-to-gate and cradle-to-end of construction embodied energy may cause a $9.2 \%$ variation in the achieved results. Retrospective research showed that the primary cause of these variations relates to the subjective delineation of system boundaries in LCEA or LCA analyses [27-29], despite several international standards and frameworks that have been developed towards this end, such as ISO14040:2006 [30] or the European frameworks developed by Technical Committee TC350, e.g., EN 15978:2011 [31]. The subjectivity in defining system boundaries can potentially compromise the quality and reliability of obtained results for decision-making purposes while limiting the possibility for cross comparing LCEA cases.

With the motivation outlined above, this study aims to propose a structured framework through which the system boundaries in LCEA research can be explicitly defined. 
The framework proposed by this paper defines system boundaries within six distinctive dimensions, facilitating the possibility for policy makers to set requirements for incorporation of embodied impacts into BEERs at national or regional levels. This framework is also expected to assist with exploring the relative body of research that can lead to broadening our understanding of building energy performance within a global context by comparing LCEA cases. The remainder of this paper unfolds as: first, the research theoretical background is explained in Section 2 in order to provide an overview of the life cycle energy assessment approach, embodied energy, and operational energy. Section 2 also provides a review of previous studies aimed at developing a framework for standardisation of system boundary definition. Section 3 elaborates on the methodological approach of the research. Different dimensions of the proposed framework are then explained in Section 4. The implementation of the proposed framework is described in Section 5 , before the discussion and conclusion in Sections 6 and 7, respectively.

\section{Theoretical Background}

\subsection{An Overview of LCEA}

The LCA is a quantitative approach to measure environmental burdens associated with processes, products, or services over their life cycles [32]. The International Organization for Standardization (ISO) introduced a framework to perform LCA analysis [33]. This framework consists of four primary steps, including (1) setting the goals and scope, (2) life cycle inventory (LCI), (3) life cycle impact assessment (LCIA), and (4) interpretation. The first step requires setting the overall goals and scope of the project along with establishing system boundaries and determining the inventory data quality requirements. The LCI is the next step whereby the process for obtaining and collating data of energy flows at each stage of a product's life cycle should be determined. This is followed by LCIA, where the environmental impacts correlated with materials and energy flows are quantified and assigned to their respective environmental impact categories. At the interpretation step, the obtained LCA results are interpreted with respect to the defined goals and scope of the research, and recommendations are issued accordingly.

LCEA is a version of the LCA that only accounts for energy usage at all stages of a building's life cycle [6,24]. In this approach, the total energy performance of a building is quantitatively assessed considering both operational and embodied energies. Embodied energy is the amount of energy consumed at the upstream and downstream stages of the building's life cycle, including production of building materials (known as initial embodied energy), building construction, maintenance and replacement (also known as recurrent embodied energy), end-of-life (EOL) processes, and transportation between any of these steps $[23,24,32]$. The operational energy refers to the amounts of energy used in the forms of thermal (i.e., heating and cooling) and non-thermal (i.e., domestic hot water (DHW), electrical appliances and equipment, ventilation, lighting, and cooking) energy over the life cycle of a building $[23,24,32]$. The scope of this study is limited to LCEA analysis; however, the final outcome can also be applicable to LCA research.

\subsection{Previous Research on Developing Frameworks for System Boundaries}

In the wider literature, a system boundary is defined in different ways. In the general system theory, Bertalanffy [8] defined a system boundary as an interaction interface whereby material, energy, or information is transferred in or out of the system. In societal system theory, this concept is described as barriers that differentiate a system from others in the environment through its spatial and temporal boundaries, any surrounding environmental affects characterised by its structure and purpose and expressed in its functionality [34]. In a narrower scope, a system boundary is defined by the ISO as a number of criteria that determine the inclusion of unit processes into a product system [33].

The absence of a standardised framework for defining system boundaries is commonly considered as a principal contributor to varying LCEA results [24,25,28,35-39]. This was first noted by Sartori and Hestnes [40] through analysing 60 cases from nine countries. 
Recent studies have also attested to the key role of system boundary definition in deriving variations and identified multiple reasons for such phenomena, e.g., varied definitions of physical and temporal boundaries; the use of different methods for measuring embodied and operational energies; buildings' geographic locations, data source, and data quality; or manufacturing technology [23,24,27,29,40]. For instance, Moncaster et al. [29] identified three major categories that contribute to varying results in embodied energy analysis, namely "temporal differences in the stages considered"; "spatial differences in the material boundaries"; and "physical disparities in the data coefficients".

Despite the significance of a system boundary in determining the quality of LCEA results, a limited number of studies have been undertaken to standardise system boundary definition. Hammond and Jones [41] introduced a four-level regression model for the description of a system boundary. The first level accounts for all of the energy inputs used directly during processes such as construction, prefabrication, maintenance, replacement, demolition, and disposal in order to produce a product. The second level of the regression model promotes the inclusion of energy consumption sequestered into main and all upstream and downstream processes of materials and product manufacturing. The third level captures the amounts of energy use embedded in the production, delivery, and installation of machines that are utilised to manufacture materials, as well as on- and off-site construction processes. The final level represents the amount of energy expelled during the main, upstream, and downstream production processes of manufacturing machinery that in turn produces the machine (of third level regression). Although the proposed model endeavours to disentangle the energy inputs used at each stage of a building's life cycle, it still fails to capture other flows of data requirements for the environmental assessment of a building. Likewise, Fay [42] presented the same ideas about defining system boundary conditions that are composed of multiple levels. A similar boundary condition was also demonstrated by Herendeen [43] through analysing the life cycle energy use of car production. The results showed that $90 \%$ of the energy is consumed during processes of producing constituents of car materials such as steel, plastic, glass, etc., whereas only $10 \%$ of energy consumption relates to car manufacturing plants.

Dixit et al. [28] also proposed a conceptual framework based on performing a comprehensive literature review and synthesising relevant literature opinions on system boundary definition. The proposed framework primarily aimed to elaborate on the temporal and physical boundaries of a system under research. The study was concluded by recommending several measures that enable conducting the LCEA of a building. Stephan et al. [39] presented a comprehensive framework of a system boundary to capture the energy requirements at both building and urban scales. The framework accounts for operational and embodied energy usage of buildings, as well as embodied impacts related to nearby infrastructures and the occupants' transport energy. Although the framework promotes the integration of energy flows between embodied, operational, and transport requirements, it does not provide tailored data requirements for different dimensions of system boundaries. In another study, Pan [44] proposed a theoretical framework to assist multi-criteria decision making in selecting off-site construction technologies. The framework captures four aspects of system boundaries, namely, ontology, epistemology, methodology, and axiology. Pan's framework enables the theoretical investigation of system boundaries defined in previous studies of LCA and carbon emissions. Later on, Pan [37] developed a conceptual model that consists of eight boundaries including "the policy timeframe, building lifecycle, geographic, climatic, stakeholder, sector, density, and institutional boundaries". This framework provides the possibility of cross comparing different cases within a harmonised context. Despite the great details provided, the life cycle boundary of the framework only elaborates on the temporal dimension of the system boundary without providing detailed information on other facets.

The frameworks developed by the reviewed studies fall short of capturing all the dimensions involved in defining system boundaries. The majority aimed at simplifying the temporal and physical dimensions, and only the study by Pan [37] elaborated on aspects 
such as building geography, stakeholders, or the relative sector. This highlights the need for a much more comprehensive framework when aiming for the incorporation of embodied impacts into BEERs. The comprehensiveness of such a framework can assist policy makers to set certain requirements and standards for each dimension of the framework at national or regional scales.

\section{Methodology}

The overall methodological approach of this paper consists of three stages. The first stage involves the identification of variables that contribute to variations in LCEA results. Previous studies have examined a number of parameters with potential influence on the LCEA results, such as data quality, functional units, or calculation methods [27,45]. However, the identified parameters reported in the existing literature were limited and sporadically sorted without any systematic understanding. Hence, comprehensive searching exercises were conducted throughout various scholarly databases, namely, Web of Science, ProQuest, and Scopus, in order to retrieve studies related to the LCEA approach. The literature review approach was a systematic approach; thus, certain limitations were considered. First, the scope of these literature analyses was limited to only residential buildings. Second, only studies that assessed the life cycle energy performance of residential buildings using primary energy were considered for detailed examinations. Despite the limitations considered, the literature review surveys managed to identify 66 LCEA research projects representing 243 case studies in over 15 countries. The findings of the literature review analysis were reported in $[23,24]$. Thereafter, the approaches of the identified studies to defining system boundary conditions in LCEA research were analysed in depth. The findings identified 12 major parameters attributed to different aspects of LCEA methodology that potentially result in varying outcomes. These parameters were further grouped into the following four categories: "system boundary definition", "calculation methods", "geographical context", and "interpretation of results". Detailed discussion of the findings of the literature review analyses is beyond the scope of this paper; thus, readers are encouraged to refer to $[23,24]$ for further details.

The second stage involves developing a comprehensive framework to standardise system boundary conditions in LCEA research using the parameters identified by analysing the literature. Figure 1 illustrates the development process of the proposed framework that began with (i) reviewing the literature where parameters causing the variations in LCEA results were singled out $[23,24]$, (ii) consolidating the identified variables into six distinguished dimensions, and (iii) allocating each variable to its respective dimension. Since the scope of the literature review was limited to residential buildings, this paper also proposes consideration of "building types" and "building density" (i.e., number of storeys) as distinctive dimensions of a system boundary in LCEA analysis. Section 4 will further elaborate on each dimension of the framework.

The third stage involves demonstrating the implementation of the proposed framework. The applicability of a framework can generally be tested through different methods such as using focused community expert groups, surveys, case studies, experiments, or simulations $[46,47]$. The current paper employs a simulation approach in order to evaluate the applicability of the proposed framework. To this end, the system boundary conditions of a residential building in Adelaide, Australia, were first defined using the proposed framework. The annual operational energy of the case study was assessed using the EnergyPlus 8.9 simulation engine [48]. Regarding embodied energy, the quantity of materials was assessed through the building's drawings. To assess the embodied impacts of building materials, a database developed by Pullen [49] was utilised in order to calculate the building's embodied energy. The results calculated in this paper were then cross compared with the results of a case study analysed by Crawford [50], aiming to demonstrate the capacity of the proposed framework for cross comparing cases within a standardised context. Afterward, the results are discussed and implications for further research are highlighted. 


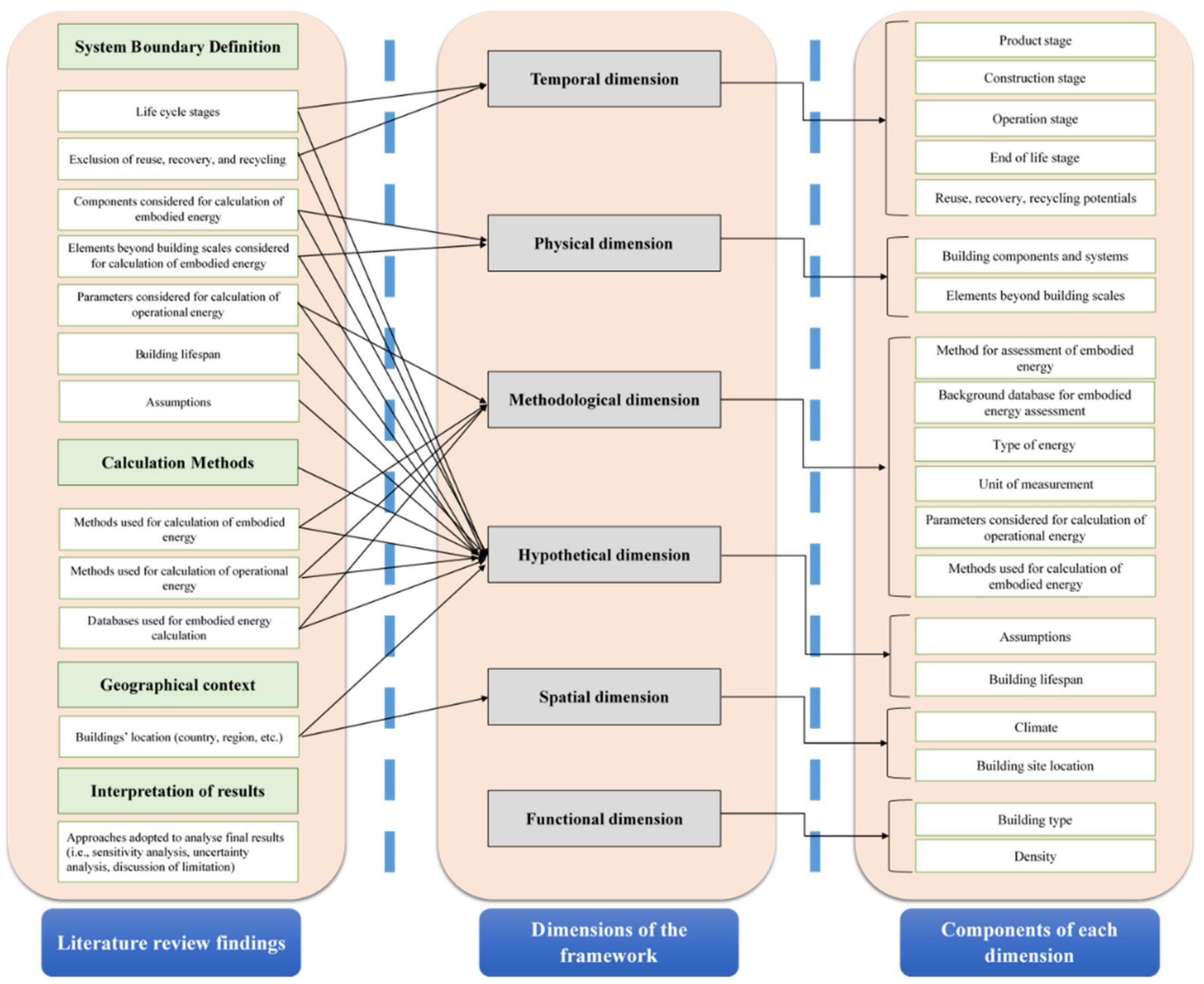

Figure 1. Different aspects of system boundaries in LCEA research.

\section{The Proposed Framework}

This paper defines a system boundary as a process of characterising attributes that are related to calculations of both embodied and operational energies. These attributes entail a wide array of data regarding the description of temporal, physical, methodological, hypothetical, spatial, and functional aspects of LCEA analysis (Table 1). The proposed framework aims to encourage the incorporation of embodied energy into BEERs by outlining a comprehensive description of system boundaries in LCEA analysis. The objectives of the proposed framework include (i) maintaining transparency in conducting the LCEA, and (ii) establishing a basis for performing cross comparison between cases within a lucid context. 
Table 1. Different dimensions of a conceptual framework for system boundaries.

\begin{tabular}{|c|c|c|c|}
\hline Boundary Dimensions & No. & Components of Boundary & Sub-Components \\
\hline 1. Temporal & $(1.1)$ & Stages of building life cycle & $\begin{array}{l}\text { Product; construction; operation; end-of-life; reuse, } \\
\text { recovery, recycling potentials. }\end{array}$ \\
\hline 2. Physical & $(2.1)$ & Building components and systems & $\begin{array}{l}\text { Substructure; superstructure; renewable energy } \\
\text { system; building services; finishes. }\end{array}$ \\
\hline- & $(2.2)$ & Elements beyond building scales & Occupants' transport; external works. \\
\hline \multirow{2}{*}{ 3. Methodological } & $(3.1)$ & $\begin{array}{l}\text { Method for assessment of } \\
\text { embodied energy }\end{array}$ & $\begin{array}{l}\text { Process-based, economic input-output (I-O), and } \\
\text { input-output-based hybrid. }\end{array}$ \\
\hline & $(3.2)$ & $\begin{array}{l}\text { Background database for } \\
\text { embodied energy assessment }\end{array}$ & $\begin{array}{c}\text { Literature; publicly or commercially available } \\
\text { databases. } \\
\text { Age of data. }\end{array}$ \\
\hline- & $(3.3)$ & Type of energy & Primary energy; delivered energy. \\
\hline- & $(3.4)$ & Unit of measurement & $\begin{array}{l}\text { Per } \mathrm{m}^{2} \text { of net conditioned floor area; whole building; } \\
\text { building component/construction material. }\end{array}$ \\
\hline- & $(3.5)$ & $\begin{array}{l}\text { Parameters contributing to } \\
\text { operational energy assessment }\end{array}$ & $\begin{array}{l}\text { Heating; cooling; DHW; electrical appliances; } \\
\text { ventilation; lighting; and cooking. }\end{array}$ \\
\hline- & $(3.6)$ & $\begin{array}{l}\text { Method for assessment of } \\
\text { operational energy }\end{array}$ & $\begin{array}{c}\text { Simulation approach; energy bills; monitoring; } \\
\text { national statistics. }\end{array}$ \\
\hline \multirow[t]{2}{*}{ 4. Hypothetical } & $(4.1)$ & Assumptions & $\begin{array}{l}\text { Temporal dimension; physical dimension; } \\
\text { calculation methods. }\end{array}$ \\
\hline & $(4.2)$ & Building lifespan & 30-100 years. \\
\hline 5. Spatial & $(5.1)$ & Climate & Tropical; dry; temperate; continental; polar. \\
\hline- & $(5.2)$ & Building site location & City; suburb; regional; remote. \\
\hline 6. Functional & $(6.1)$ & Building type & $\begin{array}{l}\text { Residential; non-residential (e.g., commercial; } \\
\text { educational; institutional; industrial etc.). }\end{array}$ \\
\hline- & $(6.2)$ & Density & Low-rise, medium-rise, and high-rise. \\
\hline
\end{tabular}

The first objective promotes enhancing the reliability of LCEA results for decisionmaking purposes. A detailed definition of system boundary conditions enables the uptake of achieved results with due considerations once the system boundary is subjected to truncation. Previous research [51] asserted that the majority of studies fail to clearly reveal their adopted system boundaries, hence it can be difficult to fully understand the extent to which the data are input to the system boundary.

Cross comparison is important regarding the second objective, as it is widely used as an approach to validate the obtained results. Cross comparing LCEA cases can also lead to advancing our knowledge about the total life cycle energy performance of buildings, i.e., the proportion of either embodied or operational energy used in the total building life cycle. This characteristic can also result in identifying best practices for the design and construction of buildings with low life cycle energy use performance. However, this needs to be done within a standardised context and with respect to the conditions of system boundaries. To date, a wide range of studies have showcased the significance of operational energy versus embodied energy (or vice versa) by cross comparing multiple case studies [32,40,52-55]. For example, Ramesh et al. [52] performed a literature review analysis aiming to cross compare 73 cases of office and residential buildings. They conclusively stated that the operational energy made up $80-90 \%$ of the overall life cycle energy usage of buildings, whereas embodied energy constituted $10-20 \%$. Furthermore, they attempted to convey a consolidated understanding of the total life cycle energy requirements of conventional residential buildings and office buildings. It was shown that the overall life cycle energy use of residential buildings can be in the range of $150-400 \mathrm{kWh} / \mathrm{m}^{2}$ per year and that of office buildings in the range of $250-550 \mathrm{kWh} / \mathrm{m}^{2}$ per year. These conclusions, driven by cross comparing LCEA cases without delving into their respective system boundaries, can be incomplete due to the varied approaches of studies for establishing system boundaries. 


\subsection{Temporal Dimension}

The temporal dimension refers to determining which stage of the building life cycle is included in the system boundary. In this regard, EN 15978:2011 [31] provides a comprehensive guideline that segregates the building life cycle into five stages (Figure 2).

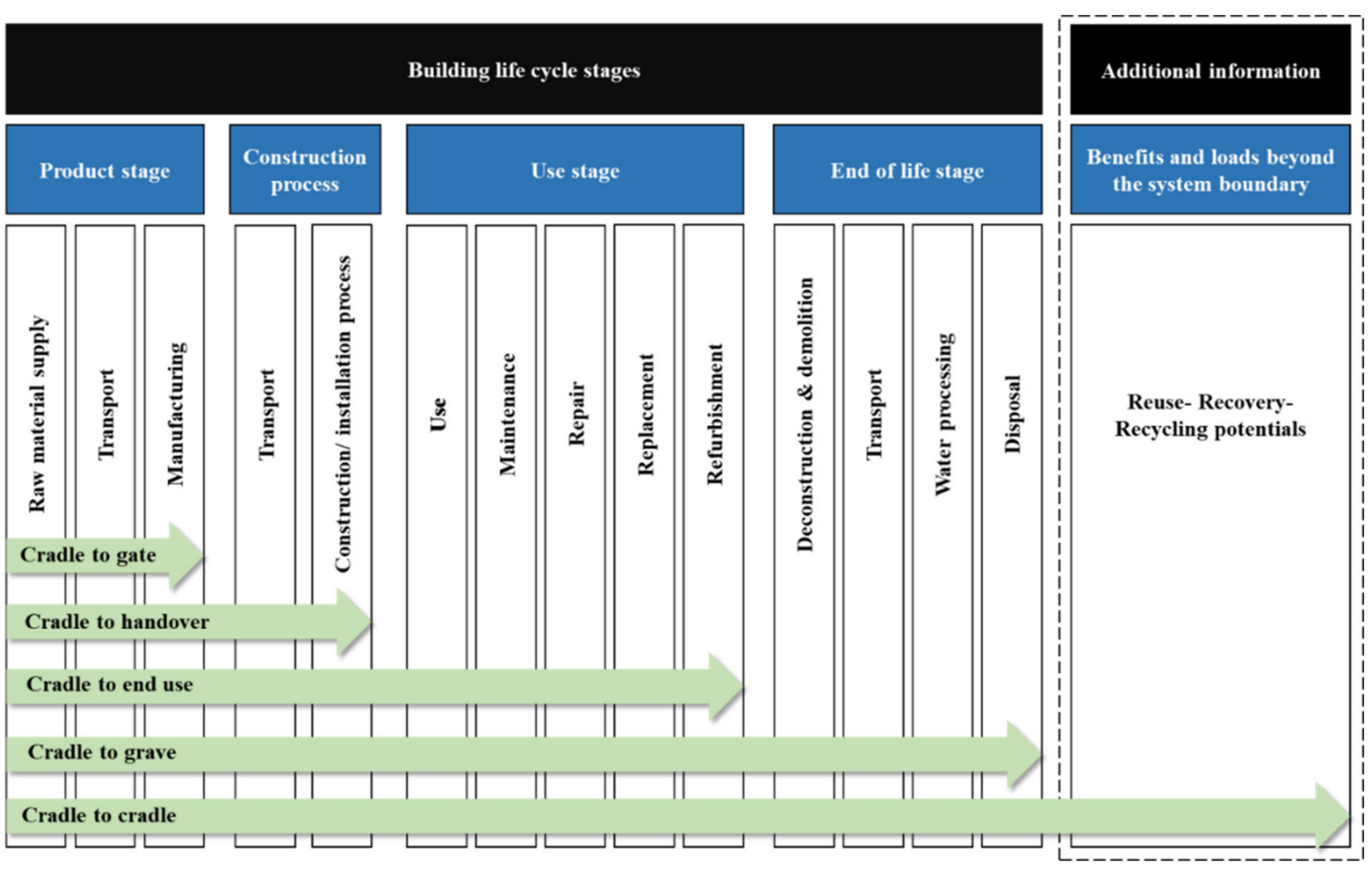

Figure 2. Proposed model for description of a system boundary (modular structure adapted from EN 15978:2011 [31]).

The cradle-to-gate includes energy inputs used for manufacturing construction materials, i.e., mining the materials, transporting the extracted materials to factories, and processing them. The cradle-to-handover includes all the processes from cradle-to-gate along with accounting for energy inputs related to transportation of materials to construction sites as well as on-site construction activities such as assembly, construction, disposal of construction wastages, etc. The cradle-to-end use refers to including energy inputs of product, construction, and use stages into the system boundary. The cradle-to-grave accounts for the amounts of energy used throughout all stages of a building's life cycle, including all the processes of upstream, downstream, and use phase. Finally, the cradle-tocradle refers to capturing the environmental benefits of construction materials beyond the defined system boundary [23].

\subsection{Physical Dimension}

The physical dimension refers to determining which building component/systems are included in the system boundary. The current LCA standards, e.g., EN 15978:2011 [31], recommend a number of building elements that can be considered for inclusion into the system boundaries. This paper complements the description of physical system boundaries of the current standards by recommending the inclusion of embodied impacts attributed to renewable energy systems and occupants' transport (Table 2). Studies have shown that embodied impacts of renewable systems, e.g., the photovoltaic system (PV) or wind turbines, can be significant $[56,57]$. In a study, Wong et al. [56] performed a comprehensive literature review analysis and concluded that the embodied energy required for the production of single-crystalline and multi-crystalline silicon PV systems amounted to $3532 \mathrm{MJ} / \mathrm{m}^{2}$ and $2876 \mathrm{MJ} / \mathrm{m}^{2}$ per year, respectively. 
Table 2. Recommended components for inclusion in a physical system boundary at building scale.

\begin{tabular}{|c|c|}
\hline Building Components & Building Sub-Components \\
\hline Substructure & Foundation \\
\hline- & Basement retaining walls \\
\hline \multirow{10}{*}{ Superstructure } & Ground floor \\
\hline & Structural building frame \\
\hline & Exterior walls \\
\hline & Exterior doors \\
\hline & Window glazing \\
\hline & Interior walls \\
\hline & Floor construction \\
\hline & Ceiling construction \\
\hline & Roof construction \\
\hline & Stairs and ramps \\
\hline \multirow[t]{3}{*}{ Fitments } & External finishes \\
\hline & Internal finishes \\
\hline & Fixed furniture \\
\hline Renewable energy system & PV systems; solar collectors; wind turbines; etc. \\
\hline \multirow[t]{7}{*}{ Building services } & Plumbing \\
\hline & Heating system \\
\hline & Cooling system \\
\hline & Ventilation system \\
\hline & Electrical system \\
\hline & Lift \\
\hline & Fire protection system \\
\hline \multirow{2}{*}{ Furniture and appliances } & Furniture \\
\hline & Appliances \\
\hline \multirow[t]{5}{*}{ External works } & Roads, path, paving and surfaces \\
\hline & Fencing, railing and walls \\
\hline & Shed \\
\hline & Pergola \\
\hline & External fixtures, drainage, and services \\
\hline Transportation & Occupants' transport \\
\hline
\end{tabular}

This study also suggests including energy use relating to occupants' transports within the physical system boundary. Previous research endeavoured to incorporate embodied energies of such elements in the system boundary [10,39,58-60]. For instance, Stephan et al. [39] put forward a framework to measure embodied impacts of nearby infrastructure (roads, water, sewage systems, etc.), combined with the energy usage of occupants' transportation. The framework was then employed to assess the total energy use of two residential buildings in Australia and Belgium. The results revealed that the occupants' transports constituted 25.40 and $33.80 \%$ of the entire building life cycle energy use in the Belgian passive house and the Australian building, respectively. Bastos et al. [59] also compared the total life cycle energy demands and greenhouse gas (GHG) emissions of two residential buildings in Lisbon, an urban apartment and a semi-detached suburban house. The analysis accounted for energy use at stages of production and operation, as well as the energy consumed due to occupants' transportation. The results indicated that the occupants' transport made up 51-57\% of the entire energy use and GHG emissions for the semi-detached house, whereas operational energy was the largest contributor to energy use and GHG emissions (63-64\%) for the apartment.

\subsection{Methodological Dimension}

As shown in Table 1, the methodological dimension contains six components that represent the key characteristics of a methodological approach for measuring embodied and operational energies. For the first component, embodied energy, there are three principal methods to compute buildings' embodied impacts, namely, the process-based, economic I$\mathrm{O}$ and hybrid analysis methods [23,24]. The process-based method collects and synthesises 
data relating to various services, products, as well as location-specific data to calculate embodied energy of construction materials [23]. These data can be retrieved from sources such as suppliers, contractors, and manufacturers. The economic I-O method utilises data representing an entire economy to quantify the amounts of energy used to generate a particular service or product. The hybrid method fuses the two methods together in order to capture energy flows from the complete upstream supply chain. Whether the application of hybrid method yields a much higher value for embodied energy, as indicated by $[15,58]$, is still a heated discussion since recent research [61] showed that the use of this method may not necessarily lead to achieving higher values due to restrictive assumptions concerned with it.

The selection of a background database is essential to calculate embodied energy. This database should contain data sets that represent the economic and technical contexts of the case study. In a comprehensive review, Omrany et al. [23] found that the databases needed for the calculation of embodied energy were collected from two main sources: literature (i.e., data published by other researchers) and databases that are available commercially or publicly. It is important to declare the database utilised for calculating embodied energy since the approach of each database towards quantification of embodied energy or embodied carbon emissions of materials can be different. For instance, the Inventory of Carbon and Energy, which contains over 200 construction materials, was developed based on the data collected via surveys and the data reported in the literature [62]. This approach differs from the ecoinvent database, which was developed based on the economic I-O approach and quantifies inputs and outputs to and from the biosphere [62]. In addition, the age of data can affect the quality of the LCEA results and subsequently influence the comparability of cases. The databases with old data represent obsolete manufacturing technologies, hence their energy values can differ from updated ones [63].

The total energy consumption of a building can be measured using either primary energy or delivered (or site line) energy. Primary energy refers to the energy that is directly extracted from nature (e.g., crude oil, or coal) and is unprocessed [24,27]. Delivered energy refers to the energy that is used on-site and produced by processing primary fuels such as electricity [24,27]. The use of primary energy for conducting LCEA research is favoured over the delivered energy since it contains higher amounts of energy; thus, the environmental impacts of buildings can be captured more accurately.

The unit of measurement (also known as functional unit) represents the life cycle energy performance of the main entity (i.e., building) that has been subjected to LCEA analysis. The unit can be expressed in different forms, namely, per $\mathrm{m}^{2}$ of net conditioned floor area, as a whole building, or it can be a particular building component or a construction material. The proper selection of unit of measurement is of the greatest importance due to its influence on the accurate presentation of the LCEA results. In a study, Stephan and Crawford [64] studied the effect of dwelling size on life cycle energy demands using a parametric approach. It was revealed that the life cycle energy demands increased at a slower rate compared to house size. Hence, the expression of the total energy-efficiency performance of buildings per $\mathrm{m}^{2}$ would favour large houses, as these require more energy. They recommended that BEERs should utilise multiple functional units to measure the energy-efficiency performance of buildings. de Simone Souza et al. [65] also employed different functional units in order to evaluate their effects on the final LCA results. The selected units included "a building with defined lifetime and occupancy parameters", LCA performance of the building per $\mathrm{m}^{2}$ over one year, and "the accommodation of an occupant person of the dwelling over a day". This indicated the effects of functional unit selection on the final results.

Energy is consumed in non-thermal and thermal forms in order to retain the comfortability of indoor environments. Thermal energy refers to the amounts of energy used for the purposes of heating and cooling, while the non-thermal includes energies used for domestic hot water (DHW), electrical appliances, ventilation, lighting, and cooking. The estimation of a building's operational energy usage depends on the extent to which system 
boundaries are set to account for the impacts of these parameters over a building's lifespan [23,24]. Exclusion of each parameter can directly affect the LCEA results by influencing the calculation of operational energy. In a study, Gustavsson and Joelsson [66] showed that the proportion of embodied energy to the total life cycle energy use of a building was reduced from 33 to $25 \%$ when the scope of assessment for operational energy was extended from only space heating to include ventilation, DHW, and household electricity.

The method applied to calculate operating energy in an LCEA analysis is another component of the methodological dimension. Recent studies $[23,24]$ revealed that four main methods, namely, "simulation", "energy bills", "monitoring", and "national statistics", have been commonly applied by LCEA studies for computing the operational energy use of buildings. It was found that most reviewed studies applied the simulation approach to calculate the energy usage of buildings. In this approach, the energy consumption of a building is calculated using a simulation engine, then the achieved figure is multiplied by the number of years assumed for building lifespan to estimate the operational energy of buildings. The energy bill is another method in which operational energy consumption is estimated using the actual energy bills of a building. In monitoring, sensors and actuators are employed to record and store the energy consumption of a building on a daily, monthly, or yearly basis. This method is similar to energy bills as both capture actual energy usage, except that monitoring can also provide a detailed breakdown of energy by use whereas the energy bills method only supplies an aggregate value for operational energy consumption [23,24]. However, several challenges are also involved in employing the monitoring method, such as interoperability, high initial cost, and the difficulty in managing and storing the monitored data [67]. National statistics also denotes a method where national or regional statistics on energy consumption in the building sector are used for estimating operational energy. The employment of this method can illustrate the divergence between actual and estimated energy consumption as these data are developed based on the average energy usage in the building sector $[23,24]$.

\subsection{Hypothetical Dimension}

Making assumptions is inevitable in performing LCEA research. Assumptions are generally made due to the lack of reliable data, or to reduce the complexities involved in calculations of embodied or operational energies [24]. The importance of assumptions is also highlighted by international LCA standards [33], and it is recommended that they should be clearly acknowledged for the sake of transparency. The assumptions are made regarding different aspects of LCEA analysis, namely, temporal, physical dimensions, and building lifespan $[23,24]$. Regarding the temporal dimension, the assumptions can be grouped as:

- Product stage: assumptions in this category are usually made due to the absence of a locally developed database. Hence, the LCEA researchers adopt the background database of another region/country in order to calculate embodied energy [10,58,68]. This subsequently compromises the accuracy and reliability of embodied energy calculations for decision-making purposes since manufacturing processes, economic sectors, construction technologies, fuel supply structure, and energy tariffs vary from one country to another.

- Operation: the most common assumption in this category relates to assuming that buildings' operational energy use will be constant throughout the entire period of assessment (e.g., for 50 years). This assumption implies that buildings' occupancy profiles will be unchanged in terms of family size or the settings of occupancy schedule, or there will be no depreciation of heating and cooling systems. Another assumption pertains to ignoring the possible effects of future climate change on the heating and cooling demands of buildings. The review conducted by Omrany et al. [23] showed that the majority of the analysed studies calculated operational energy use of buildings considering only the current climatic conditions. However, the findings reported by 
recent studies have indicated that the heating and cooling demands of buildings can be affected by climate change [69].

- Recurrent embodied energy: there are also several assumptions made about this stage. The most common assumption is that building materials will be replaced with the same materials as they reach their end of service lives. Thus, they will incur the same amounts of embodied energy as original materials.

- Construction and EOL: due to numerous uncertainties involved, the common approach to account for the embodied impacts of these stages is to assume certain values as their respective contributions to the buildings' total embodied energies [23,24]. For instance, Gustavsson et al. [70] assumed that the primary energy used for the on-site construction of an eight-story apartment equalled $80 \mathrm{kWh} / \mathrm{m}^{2}$. Devi and Palaniappan [68] also assumed that the EOL stage consumed 3\% of the total initial embodied energy.

The assumption of building lifespan is of utmost importance in an LCEA analysis owing to its direct influence on both operational and embodied energies. The embodied energy (i.e., recurrent embodied energy) can be affected by the assumption of building lifespan when assuming a long lifespan leads to frequent substitutions of building materials, while assuming a short lifespan triggers the need for changing the entire building. This assumption can also influence operational energy because extending the lifetime of a building results in an increase in energy consumption over its service life. Recent studies indicated that the range of building lifespans assumed by relevant literature falls within a range of 30 to 100 years $[23,24]$. The physical dimension can also contain assumptions. This may relate to the process of obtaining and compiling bills of quantity for the calculation of a building's embodied impacts where reliable data are unavailable.

In sum, all the assumptions need to be clearly stated in LCEA research while justifying their contextual applicability.

\subsection{Spatial Dimension}

The climate directly influences the operational energy use of buildings by affecting heating and cooling demands. In this framework, the spatial dimension is used as a proxy for a building's geographical location to describe the climate zone. This study uses the Köppen climate classification scheme [71] to elaborate on the spatial dimension of system boundaries. This scheme introduces five main climatic conditions, including tropical, dry, temperate, continental, and polar and each has its own subtypes.

The building site location is another component of the spatial dimension that refers to the travelling distance between a building's site location and urban facilities. Disclosure of this component can help with maintaining transparency for calculation of transport embodied energy as well as being a sub-component of the occupants' transport in the physical dimension.

\subsection{Functional Dimension}

The functional dimension refers to determining the type of building and density. The building types are commonly categorised as residential and non-residential buildings. Non-residential buildings include commercial, educational, institutional, industrial, etc. The number of storeys can also be used to describe the density of buildings, as suggested by Jan et al. [72]. Building density can directly impact LCEA results by affecting initial embodied energy use. Wang et al. [73] investigated the life cycle energy use of ten real-life buildings in Hong Kong and reported that the initial embodied energy usage of high-rise buildings was twice that of low-rise ones. Du et al. [74] also reviewed 42 case buildings and conclusively stated that high-rise buildings used almost 50\% more embodied energy compared to low-rise buildings. Treloar et al. [75] highlighted an even larger difference, stating that high-rise buildings may use approximately $60 \%$ more initial embodied energy per unit of gross floor area than low-rise buildings. The higher embodied energy of highrise buildings can be related to (i) using more materials, and (ii) using materials with 
higher energy intensity, e.g., concrete and steel [73]. Therefore, building density needs to be captured in defining the system boundary.

\section{Implementation of the Framework}

This section aims to demonstrate the applicability of the proposed framework. To this end, the total life cycle energy performance of an NZEB building that is a single-storey detached residential building located in Adelaide, South Australia, was analysed. The proposed framework was used to define the system boundary conditions of the LCEA analysis. Afterward, the proposed framework was employed in order to compare the achieved LCEA results with the results of a case study reported in the literature [50]. The case study retrieved from the literature was selected based on two principal considerations:

- The total life cycle energy performance of the case study must be analysed, with its results explicitly reported.

- The case study should provide enough data to reflect the six main dimensions of the framework.

The main purpose of this comparison was to illustrate the capacity of the proposed framework for revealing the conditions of system boundaries when cases are horizontally compared. This further helps to make decisions on normalising the identified differences.

\subsection{Description of the Case Studies}

Figure 3 demonstrates the schematic design of the NZEB-Adelaide case study. Both buildings represent the bulk of the new dwellings that are currently being constructed across Australia. Table 3 shows the main characteristics of the buildings. Further info regarding the Melbourne case study can be found in [50].

Table 3. Characteristics of the case studies.

\begin{tabular}{|c|c|c|}
\hline Characteristics & NZEB-Adelaide Case Study & Melbourne Case Study \\
\hline Gross floor area $\left(\mathrm{m}^{2}\right)$ & 189.85 & 291.30 \\
\hline Net conditioned floor area $\left(\mathrm{m}^{2}\right)$ & 146.78 & 254.40 \\
\hline External walls & $\begin{array}{c}\text { Brick veneer; glass fibre batt insulation; average } \\
\text { U-value } 0.659 \mathrm{~W} / \mathrm{m}^{2} \mathrm{~K}\end{array}$ & $\begin{array}{l}\text { Insulated timber-framed brick } \\
\text { veneer walls }\end{array}$ \\
\hline Footings/ground floor & $\begin{array}{c}\text { Concrete slab on ground consisting of steel, concrete, } \\
\text { blinding and membrane }\end{array}$ & Concrete waffle pod slab \\
\hline Pitched roof & Clay tile; roofing felt & Concrete-tiled roof \\
\hline Ceiling & Glass fibre batt; gypsum plasterboard & Not reported \\
\hline Internal walls & Insulated gypsum plasterboard & $\begin{array}{c}\text { Painted plasterboard internal } \\
\text { linings }\end{array}$ \\
\hline Windows & $\begin{array}{l}\text { Single glazed } 4 \mathrm{~mm} \text { window panes with wooden } \\
\text { frames. U-value } 6.70 \mathrm{~W} / \mathrm{m}^{2} \mathrm{~K} ; \mathrm{SHGC}^{1}=0.570\end{array}$ & Clear float glass $4 \mathrm{~mm}$ panes \\
\hline Infiltration $(\mathrm{ac} / \mathrm{h}$ at $50 \mathrm{~Pa})$ & 15.0 & Not reported \\
\hline Lighting & $\begin{array}{c}\mathrm{LED} ; 2.50 \mathrm{~W} / \mathrm{m}^{2}-100 \text { lux (normalised power } \\
\text { density) }\end{array}$ & Not reported \\
\hline Occupancy & Four people (i.e., a couple with two kids) & Not reported \\
\hline Ventilation systems & Split air conditioner system-reverse cycle & $\begin{array}{c}\text { Gas ducted heating system, and an } \\
\text { evaporative cooling system }\end{array}$ \\
\hline
\end{tabular}

NB: ${ }^{1}$ Solar heat gain coefficient. 


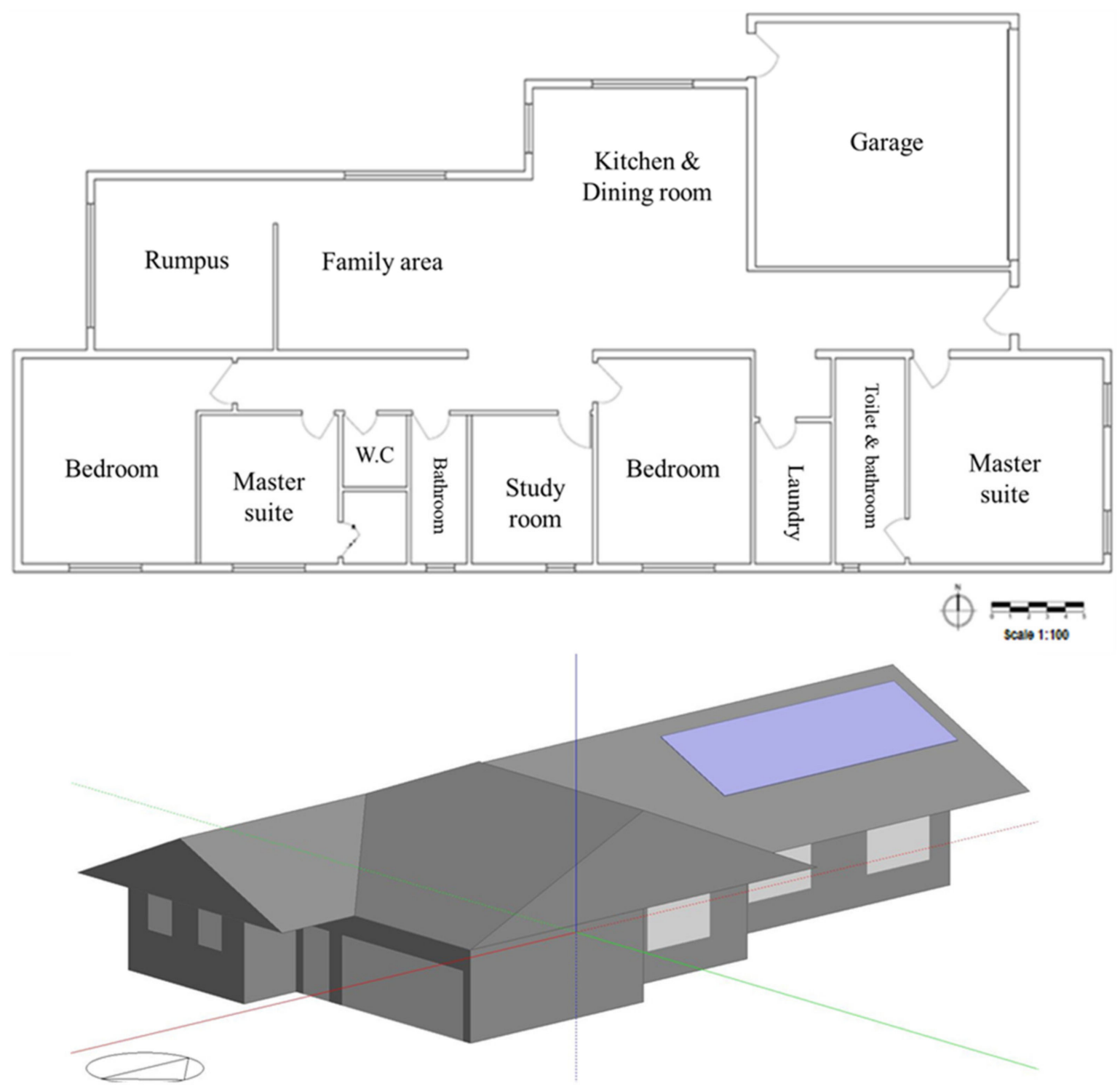

Figure 3. NZEB-Adelaide Case Study analysed by this paper. Details regarding the Melbourne Case Study can be found in [50].

Heating and cooling of the Adelaide case study were provided via a split air conditioner system-reverse cycle using electricity supplied from the grid. The coefficient of performance (COP) of the heating system was assumed to be 2.25 , with the maximum capacity of supplying $35.0^{\circ} \mathrm{C}$ air temperature. The $\mathrm{COP}$ of the cooling system was assumed to be 1.80 with the maximum supply air temperature of $12.0^{\circ} \mathrm{C}$. The Melbourne case study used a gas ducted heating system and an evaporative cooling system. An instantaneous gas-boosted solar hot water system was also used to provide hot water [50].

\subsection{Definition of the System Boundary}

The main dimensions of the system boundaries defined by both case studies are shown in Table 4. The use of the proposed framework enabled delineating system boundaries within a lucid context so that any truncation with potential effects on the LCEA results could be identified. 
Table 4. Demonstrating the implementation of the proposed framework.

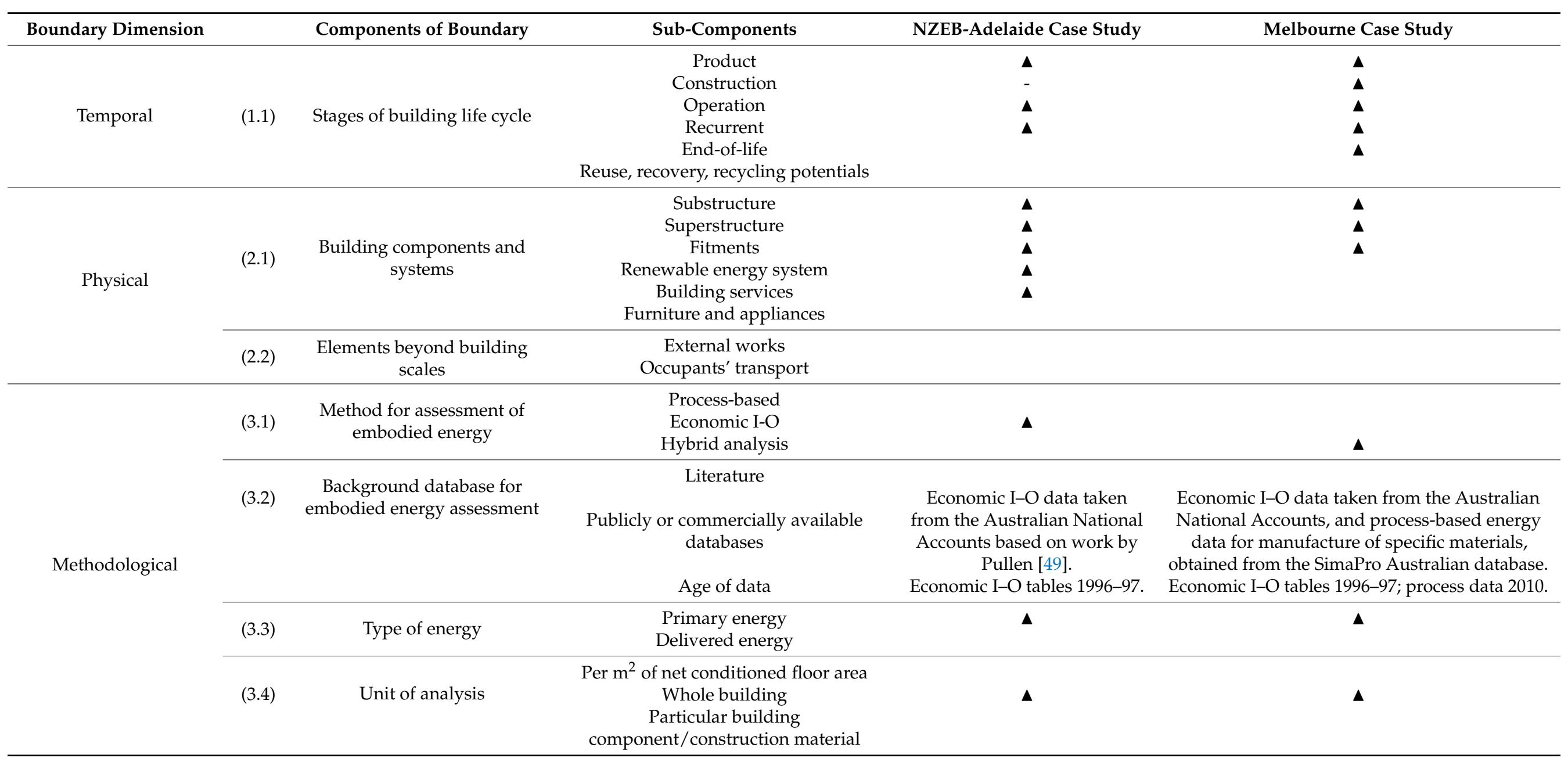


Table 4. Cont

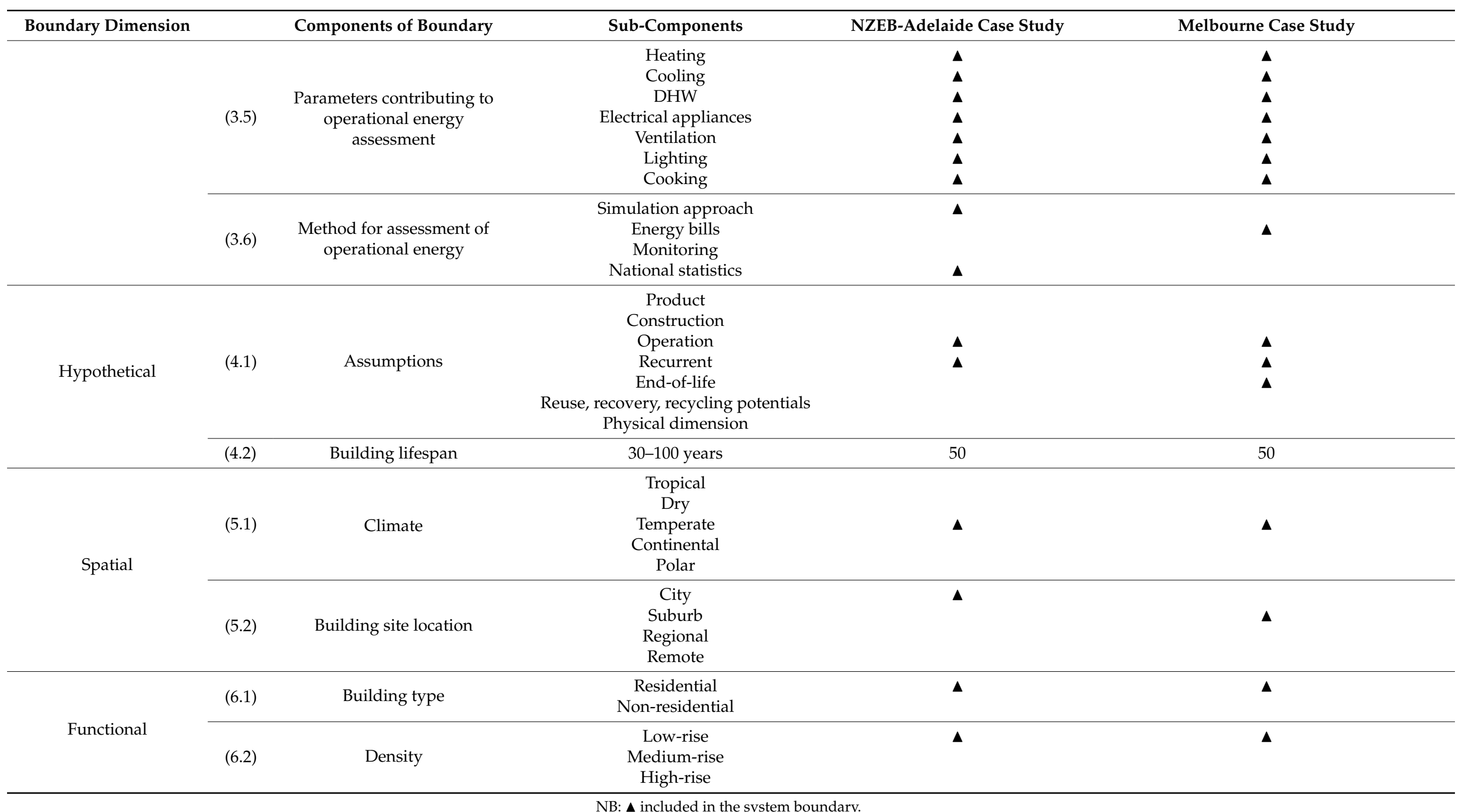

NB: $\boldsymbol{\Lambda}$ included in the system boundary. 


\subsubsection{Temporal Dimension}

The total life cycle energy use of the NZEB-Adelaide case study was assessed considering the product, operation, and recurrent stages of the building life cycle. The embodied impacts associated with the EOL and construction stages were excluded from the system boundary due to several uncertainties concerning the calculation of these stages, e.g., difficulty in gathering and documenting reliable data during on-site construction operations or the uncertain fate of materials after deconstructing the building [23]. Moreover, previous studies showed that these stages make minor contributions to the building's overall life cycle consumptions [76,77]. Regarding the recurrent embodied energy, Table 5 tabulates the service lives of construction materials that are assumed by both studies to be replaced over the 50 years of building operations.

Table 5. Service lives of materials subjected to replacement over the buildings' life spans.

\begin{tabular}{ccc}
\hline \multirow{2}{*}{ Building Materials } & NZEB-Adelaide Case Study * & Melbourne Case Study \\
\cline { 2 - 3 } & Service Life (Years) & Service Life (Years) \\
\hline Roof tiles & 25 & 25 \\
Paint for external surfaces & 15 & 10 \\
Plasterboard (10 mm) & 25 & 30 \\
Ceramic tiles & 25 & 25 \\
Carpet & 10 & 25 \\
PV panels & 25 & NA \\
\hline
\end{tabular}

NB: Source: a Dixit [78].

For the Melbourne case study, the LCEA assessment was undertaken considering all the stages of building life cycle, including product, construction, operation, recurrent, and EOL. Crawford [50] considered the construction stage as a component of initial embodied energy, and to account for its impacts, the material quantities $\left(Q_{m}\right)$ were multiplied by their respective embodied energy coefficient $\left(E C_{m}\right)$ in order to compute the total processbased hybrid embodied energy of the building. Afterward, the total I-O-based energy requirements of the processes for which material quantities were obtained $\left(T E R_{m}\right)$ in gigajoule (GJ) per Australian Dollar (AUD) from the I-O model were deducted from the total energy requirement of the residential building sector $\left(T E R_{r b}\right)(0.0106 \mathrm{GJ} / \mathrm{AUD})$ in order to obtain the remainder, thus correcting sideways and downstream truncation errors. To calculate the overall initial embodied energy of the house (IEE), the remainder needed to be converted from GJ/AUD to GJ/house using the estimated costs of the building construction and then added to the process-based hybrid embodied energy value. The approach for calculation of initial embodied energy can be expressed as Equation (1).

$$
\mathrm{IEE}=\sum_{m=1}^{M}\left(Q_{m} \times E C_{m}\right)+\left(T E R_{r b}-\sum_{m=1}^{M} T E R_{m}\right) \times C_{h}
$$

where IEE is the initial embodied energy of the building; $Q_{m}$ represents quantities of delivered materials; $E C_{m}$ is the embodied energy coefficients of the materials; $T E R_{r b}$ is the total energy requirements of the residential building sector in GJ per AUD; TER $R_{m}$ is the total energy requirement of the I-O-based processes representing the materials for which process data were collected, in GJ per AUD; $C_{h}$ is the cost of the house, in AUD. Regarding the EOL stage, an amount equal to $1 \%$ of the total life cycle energy demand of the dwelling was assumed to be added to the final calculated value in order to account for the embodied impacts of the stage.

\subsubsection{Physical Dimension}

The elements included in the physical system boundaries of both case studies are shown in Table 6. As indicated, the NZEB-Adelaide building has PV panels installed on the sloped roof to neutralise the household electrical energy use. The system was sized 
considering the average annual solar exposure in Adelaide, which is $20.39 \mathrm{MJ} / \mathrm{m}^{2}$ [78]. To harvest the maximum solar radiation, the PV panels were oriented towards the true north and tilted $23.0^{\circ}$. The size of PV panels was $1.639 \mathrm{~m} \times 0.982 \mathrm{~m}$, with an efficiency rate of $80 \%$. The embodied energy calculation excludes the balance of system, and only accounts for PV panels.

Table 6. Building elements included in the physical dimension.

\begin{tabular}{|c|c|c|c|}
\hline $\begin{array}{c}\text { Building } \\
\text { Components }\end{array}$ & $\begin{array}{c}\text { Building } \\
\text { Sub-Components }\end{array}$ & $\begin{array}{l}\text { NZEB-Adelaide } \\
\text { Case Study }\end{array}$ & $\begin{array}{l}\text { Melbourne Case } \\
\text { Study }\end{array}$ \\
\hline \multirow[t]{3}{*}{ Substructure } & Foundation & $\Delta$ & $\Delta$ \\
\hline & $\begin{array}{l}\text { Basement retaining } \\
\text { walls }\end{array}$ & NA & NA \\
\hline & Ground floor & $\Delta$ & $\Delta$ \\
\hline \multirow[t]{9}{*}{ Superstructure } & $\begin{array}{l}\text { Structural building } \\
\text { frame }\end{array}$ & $\Delta$ & $\Delta$ \\
\hline & Exterior walls & $\Delta$ & $\Delta$ \\
\hline & Exterior doors & $\bar{\Delta}$ & $\bar{\Delta}$ \\
\hline & Window glazing & $\Delta$ & $\Delta$ \\
\hline & Interior walls & $\bar{\Delta}$ & $\Delta$ \\
\hline & Floor construction & $\Delta$ & $\Delta$ \\
\hline & Ceiling construction & $\Delta$ & $\Delta$ \\
\hline & Roof construction & $\Delta$ & $\Delta$ \\
\hline & Stairs and ramps & NA & NA \\
\hline \multirow[t]{3}{*}{ Fitments } & External finishes & $\begin{array}{l}\text { Paint on external } \\
\text { walls }\end{array}$ & $\begin{array}{l}\text { Paint on external } \\
\text { walls }\end{array}$ \\
\hline & Internal finishes & $\begin{array}{c}\text { Ceramic tiles and } \\
\text { carpet }\end{array}$ & $\begin{array}{c}\text { Ceramic tiles and } \\
\text { carpet }\end{array}$ \\
\hline & Fixed furniture & Kitchen cabinet & NA \\
\hline $\begin{array}{l}\text { Renewable energy } \\
\text { system }\end{array}$ & $\begin{array}{l}\text { Photovoltaic panels; } \\
\text { solar collectors; wind } \\
\text { turbines, etc. }\end{array}$ & PV panels & NA \\
\hline \multirow[t]{7}{*}{ Building services } & Plumbing & $\begin{array}{l}\text { Piping; steel sinks; } \\
\text { taps/fittings; water } \\
\text { services; baths }\end{array}$ & NA \\
\hline & Heating system & NA & NA \\
\hline & Cooling system & NA & NA \\
\hline & Ventilation system & NA & NA \\
\hline & Electrical system & NA & NA \\
\hline & Lift & NA & NA \\
\hline & Fire protection system & NA & $\begin{array}{l}\text { NA } \\
\text { NA }\end{array}$ \\
\hline \multirow[t]{2}{*}{$\begin{array}{l}\text { Furniture and } \\
\text { appliances }\end{array}$} & Furniture & NA & NA \\
\hline & Appliances/equipment & $\begin{array}{l}\text { Oven/hob; air } \\
\text { conditioner }\end{array}$ & $\begin{array}{l}\text { Heating, hot water } \\
\text { and cooking } \\
\text { appliances }\end{array}$ \\
\hline \multirow[t]{5}{*}{ External works } & $\begin{array}{l}\text { Roads, path, paving } \\
\text { and surfaces }\end{array}$ & NA & NA \\
\hline & $\begin{array}{l}\text { Fencing, railing and } \\
\text { walls }\end{array}$ & NA & NA \\
\hline & Shed & NA & NA \\
\hline & Pergola & NA & NA \\
\hline & $\begin{array}{l}\text { External fixtures, } \\
\text { drainage, and } \\
\text { services }\end{array}$ & NA & NA \\
\hline Transportation & Occupants' transport & NA & NA \\
\hline
\end{tabular}




\subsubsection{Methodological Dimension}

The background database employed for the calculation of embodied energy in the NZEB-Adelaide case study is based on an economic I-O approach, developed by Pullen [49]. The economic I-O approach utilises the entire structure of an economy as the theoretical boundary of a system in order to compute the amounts of energy used to produce a particular material. This method has a wider approach towards calculating embodied energy compared to the process-based method due to its accounting for both the direct and indirect effects of the upstream supply chain. Cabeza et al. [79] found that studies with an economic I-O approach reported larger embodied impacts owing to the inclusion of indirect effects. On the other hand, Crawford [50] adopted an I-O-based hybrid analysis for calculating the embodied energy impacts of the building. The I-O model of Australian energy use was developed using economic I-O data retrieved from the Australian National Accounts in 1996-97, and the process-based energy data for manufacturing specific materials were acquired from the SimaPro Australian database. To streamline the assessment process, he derived a number of embodied energy coefficients for building materials [15] through which the overall embodied impacts of materials were calculated via multiplying the relevant coefficients by their quantities.

The LCEA analyses for both case studies were carried out based on primary energy consumption while accounting for all parameters contributing to thermal and non-thermal energy use. Regarding the NZEB-Adelaide case study, this study adopted a "simulation approach" to estimate the operational energy usage. To this end, the case study model was first developed in DesignBuilderV6 software, and then the thermal and non-thermal loads (including electrical appliances and lighting) were calculated using the EnergyPlus 8.9 simulation engine. EnergyPlus considers detailed interactions of all building components and systems such as building envelope, windows, HVAC, and internal heat gains from different systems in order to calculate heating and cooling loads [48]. The estimated loads were then converted into energy use by applying the assumed coefficient of performance (COP) of the equipment. After this conversion, the primary energy consumption was calculated using an electricity conversion factor of 3.40 for Australia [39]. Due to the software's limitation in simulating gas consumption, the amount of natural gas used for cooking and hot water was estimated based on national statistics for South Australia, which is $15 \mathrm{GJ}$ per household per year [80]. Thereafter, a primary energy factor of 1.40 [39] was used to convert natural gas use into primary energy consumption.

The "energy bill" approach was utilised by Crawford [50] in order to calculate the building's operational energy use. To do this, the total annual delivered operational energy requirement was estimated by averaging energy bills (including both thermal and nonthermal energy use) of the house for three consecutive years. The delivered energy use was then converted into primary energy consumptions using relevant converting factors for electricity and natural gas.

\subsubsection{Spatial Dimension}

According to the Köppen climate classification, Adelaide has a hot Mediterranean climate (Csa) with cool to mild winters and warm to hot summers that require consuming energy for both heating and cooling. Melbourne has a temperate oceanic climate $(\mathrm{Cfb})$ with ample precipitation and rainfall during the entire year. Similar to Adelaide, energy is needed for addressing heating and cooling demands throughout the year in Melbourne. Figure 4 illustrates the monthly average ambient air temperature for Adelaide airport and Melbourne airport between 1991 and 2020. According to this figure, February and July are the peak energy demands for cooling and heating in both cities, respectively [80]. 

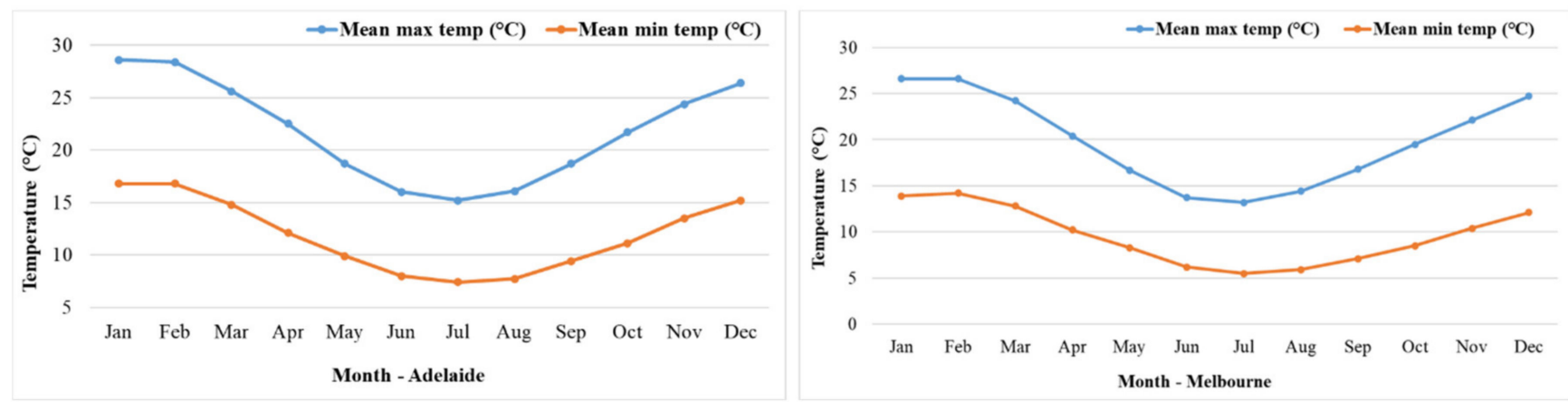

Figure 4. Monthly average ambient air temperature for Adelaide [48], and Melbourne [77].

\subsubsection{Hypothetical Dimension}

The operational energy for both case studies was assessed assuming that the occupational settings (e.g., scheduling and occupancy profile) would remain unchanged over the period of 50 years. It is also assumed that performance coefficients of electrical equipment and appliances, as well as the efficiency rate of PV panels used in the NZEB-Adelaide case study, would be constant during the entire assessment period. Furthermore, the resource mix supplying electricity to the buildings was assumed for both cases to be unchanged over the 50 years. It is also noteworthy to mention that neither of the cases accounted for the effects of future climate change on heating and cooling energy demands.

In addition, both studies assumed that certain building elements were subject to periodic maintenance and replacement (i.e., recurrent embodied energy) (See Table 5). To calculate the recurrent embodied energy, it was necessary to assume that these materials would be substituted with the same materials, thus incurring the same amounts of embodied energy as the originals. Regarding the EOL stage, Crawford [50] assumed that the energy needed for deconstruction and disposal of materials amounted to $1 \%$ of the overall life cycle energy consumption of the building.

The life span of the NZEB-Adelaide case study was assumed to be 50 years, as recommended by ASHRAE and U.S. Green Building Council (USGBC) [81]. Recent studies have also shown that most of the research analysed considered a life service of 50 years [23,24]. Similarly, Crawford [50] performed the LCEA analysis assuming 50 years of building life service. In addition, the unit of measurements utilised to report the LCEA analysis is "entire building" for both cases.

\subsubsection{Functional Dimension}

Both of the case studies are single-storey detached residential buildings that belong to the "residential" and "low-rise" sub-components of the functional dimension. The NZEBAdelaide case study represents the bulk of new dwellings being presently constructed by volume builders in Australia (Figure 4) [82]. Currently, all new buildings need to meet certain thermal requirements the equivalent of 6.0 stars in order to substantiate their compliance with the energy-efficiency regulations in Australia [83]. According to the Commonwealth Scientific and Industrial Research Organisation (CSIRO), most of the accredited buildings fall in the range of 6.0 to 6.9 stars [83]. Being 6.6 stars, the NZEBAdelaide case study met the minimum mandatory thermal requirements for residential buildings specified by national construction codes in Australia. Detailed information regarding the Australian building energy codes can be found in $[84,85]$.

\subsection{Analysis of the Case Studies}

Figure 5 illustrates the breakdowns of the total life cycle energy requirements of both cases. For the NZEB-Adelaide case study, it indicates that operational energy use constituted the largest portion of the total life cycle energy use of the building $(51.80 \%)$, followed 
by the initial embodied energy (28.3\%), and the recurrent embodied energy $(19.9 \%)$. The amount of operational energy usage estimated for the NZEB case was relatively lower than the Melbourne case. This difference can be explained by the varied approaches of the two studies to the estimation of operational energy use. The use of the energy bills approach allowed to comprehensively capture the variety of occupant behaviours in using energy, thus the potential variability between the predicted (simulated) and actual energy performance of the building was zero. Contrarily, a discrepancy can potentially occur in the simulation approach since it relied on only one pre-defined occupational profile setting in order to quantify energy consumption for an entire year. The study by Van Dronkelaar et al. [86] showed that the magnitude of deviation between simulated and measured energy use in buildings can be $+34 \%$ with a standard deviation of $55 \%$ based on 62 buildings investigated. Another reason may be due to the calculations of natural gas consumption in the two studies. For the Melbourne case, the primary energy consumption of natural gas was estimated to be $8.02 \mathrm{GJ}$ (i.e., $2336.50 \mathrm{GJ}$ ) over 50 years of building operation that included cooking, hot water, and heating [50]. However, the natural gas consumption in the case of the NZEB building (i.e., 1050 GJ over 50 years) only accounted for hot water and cooking since heating demand was supplied via electricity [80].

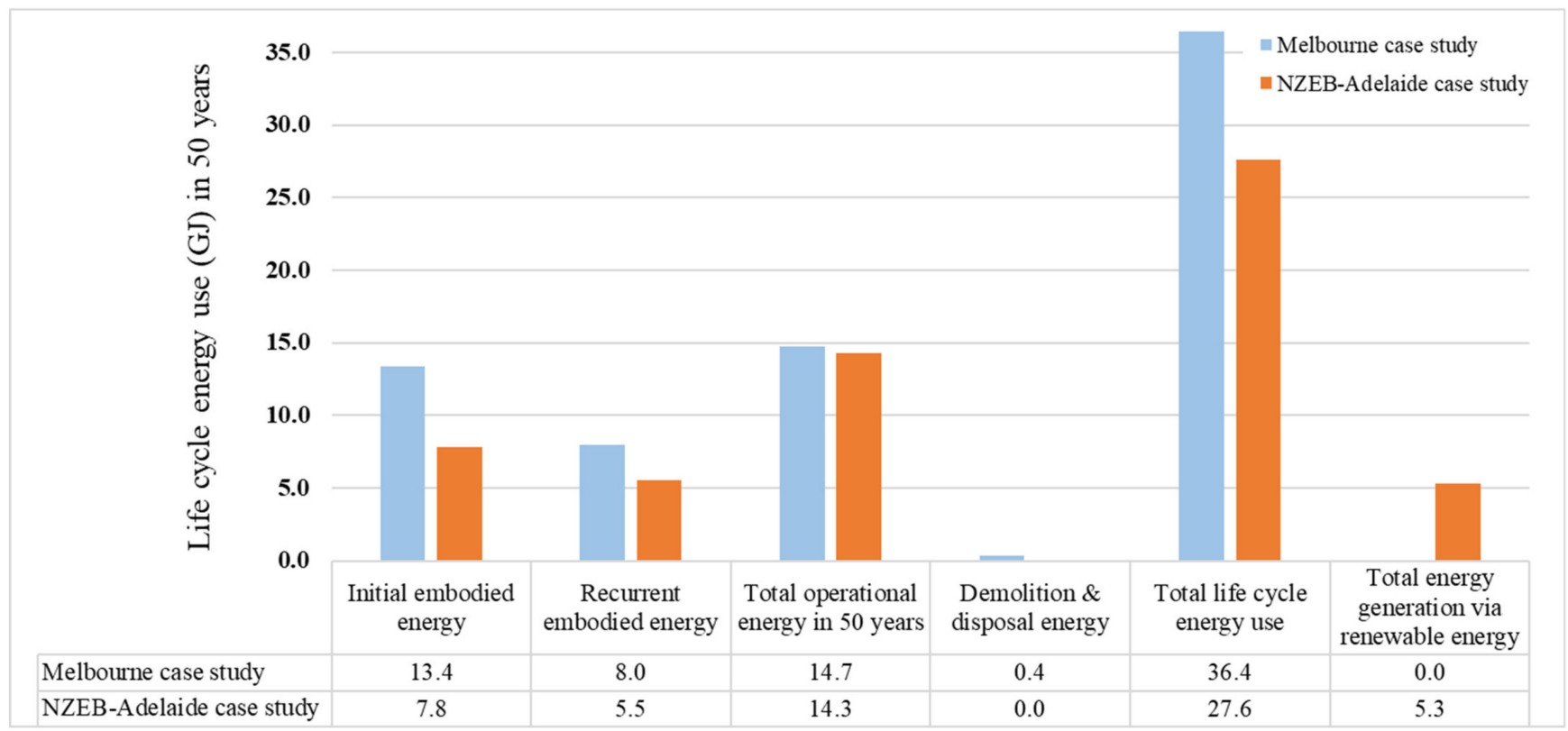

Figure 5. Life cycle energy use of the case studies normalised per square meter of gross floor areas over 50 years.

The initial embodied energy calculated for the Melbourne case study was significantly higher than the value achieved for the NZEB-Adelaide case study (Figure 5). This difference can be related to the hybrid life cycle approach applied by Crawford [50] to carry out LCEA analysis. Studies by Crawford [15] and Stephan and Stephan [58] showed that the application of a hybrid life cycle approach can yield higher embodied energy values by 3.8 and 3.9 times compared to other methods, respectively. Moreover, Crawford [50] counted the energy usage of the construction stage towards initial embodied energy, as explained in the section on temporal dimension, whereas the NZEB-Adelaide case study excluded the construction stage. The higher recurrent embodied energy of the Melbourne case study can also be explained by the wider approach used by Crawford [50] for calculating the embodied impacts of the building. It is noteworthy to mention that both case studies assumed that materials would be replaced by the same ones when they reached their end of service lives, thus having the same amounts of embodied energy impacts as originals.

In addition, the two studies differed in terms of establishing their temporal and physical dimensions of the system boundaries. Crawford [50] accounted for the impacts 
of the EOL stage by adding $1 \%$ of the total life cycle energy demand to the final figure calculated for the LCEA performance of the building. On the other hand, the NZEBAdelaide case study included the embodied impacts of PV panels in the physical dimension of the system boundary, which affects both initial embodied and recurrent energies. The $\mathrm{PV}$ panels were engaged to zero out the electrical energy demands of the building, which led to generating $1013.844 \mathrm{GJ}$ of energy over the 50 years.

\section{Discussion}

The importance of reducing embodied energy has become a hostile debate in recent years due to its increasing contribution to energy consumption in the built environment. The World Green Building Council predicted that embodied carbon driven from the embodied energy of construction projects will be responsible for more than $50 \%$ of the entire carbon emissions by 2050 worldwide [26]. The results of this study also revealed that embodied energy constituted 60 and $48 \%$ of the total life cycle energy demands of the Melbourne and Adelaide case studies, respectively. In this regard, studies discerned that, without immediate action, embodied energy will be an impending environmental concern related to the performance of buildings [45]. Therefore, there has been an increasing demand for mitigation of embodied energy in the built environment over the last decade.

One approach to minimise the impacts of embodied energy is to incorporate such a requirement into current BEERs. Thus far, only a few countries have started incorporating embodied energy into their building regulations. The Netherlands was the first country to introduce requirements for the measurement, though not the reduction, of embodied impacts into its building regulations $[87,88]$. Other countries have also taken their first steps towards this end such as France [79], Finland [89], Norway [89], Denmark [90,91], and Sweden [92]. However, the abatement of embodied energy as a requirement mandated by BEERs is still being neglected by most countries [45]. One of the main reason for such an exclusion lies with the complexities involved in assessing embodied energy in conjunction with operational energy. The assessment of embodied energy is less straightforward compared to operational energy owing to the various intertwined processes involved, as well as several variables that should be counted towards the assessment of embodied energy. This paper proposed a comprehensive framework to standardise system boundary conditions in LCEA research. The overarching aim of the framework is to encourage the incorporation of embodied energy into building regulations by (i) identifying the main parameters causing variation in LCEA results, and (ii) structuring the identified parameters into six dimensions. Although the case studies analysed by this paper are located in Australia, the framework can be adopted by other countries for the purpose of standardising LCEA analysis.

The proposed framework has two key characteristics. First, its application facilitates defining the conditions of a system boundary within a transparent context. This, in turn, will lead to increasing the reliability of obtained LCEA results for decision-making purposes, since any particular conditions (e.g., truncation, or assumption) considered in establishing the boundaries of the system under study can be revealed. In addition, the use of the proposed framework provides a meaningful basis for cross comparing cases within a global context. This can further result in identifying best practices for the design of buildings with low life cycle energy use performance. In regard to policy making, the framework introduces 15 variables that are categorised into six distinguished dimensions. The policy makers can set certain requirements and standards for each dimension to be practised within a national or a regional level. As an illustration, Birgisdóttir et al. [93] suggested that cradle-to-handover (See Figure 2) should be considered as the minimum requirements for assessing the energy of buildings. The Norwegian Research Centre on Zero Emission Buildings also presented different levels of data requirements for assessment of buildings' embodied emissions [94].

The incorporation of embodied energy impacts into BEERs also requires revising the current mindset of policy making in the building sector. In general, the implementation of 
energy policies has three components, i.e., "sticks", "tambourines", and "carrots" [95,96]. In the building sector context, sticks represent regulations, codes, and standards through which a benchmarking basis is provided to identify non-compliant buildings with the given requirements. The tambourines are the tools employed to enhance public awareness about compliance requirements and energy-saving strategies such as building labelling. The carrots refer to the incentives considered for encouraging the best practices in the building sector such as subsidies and rebates or loans. The change in mindset should occur in all the three pillars of energy policy implementation in order to accommodate the inclusion of embodied energy into BEERs (Figure 6).

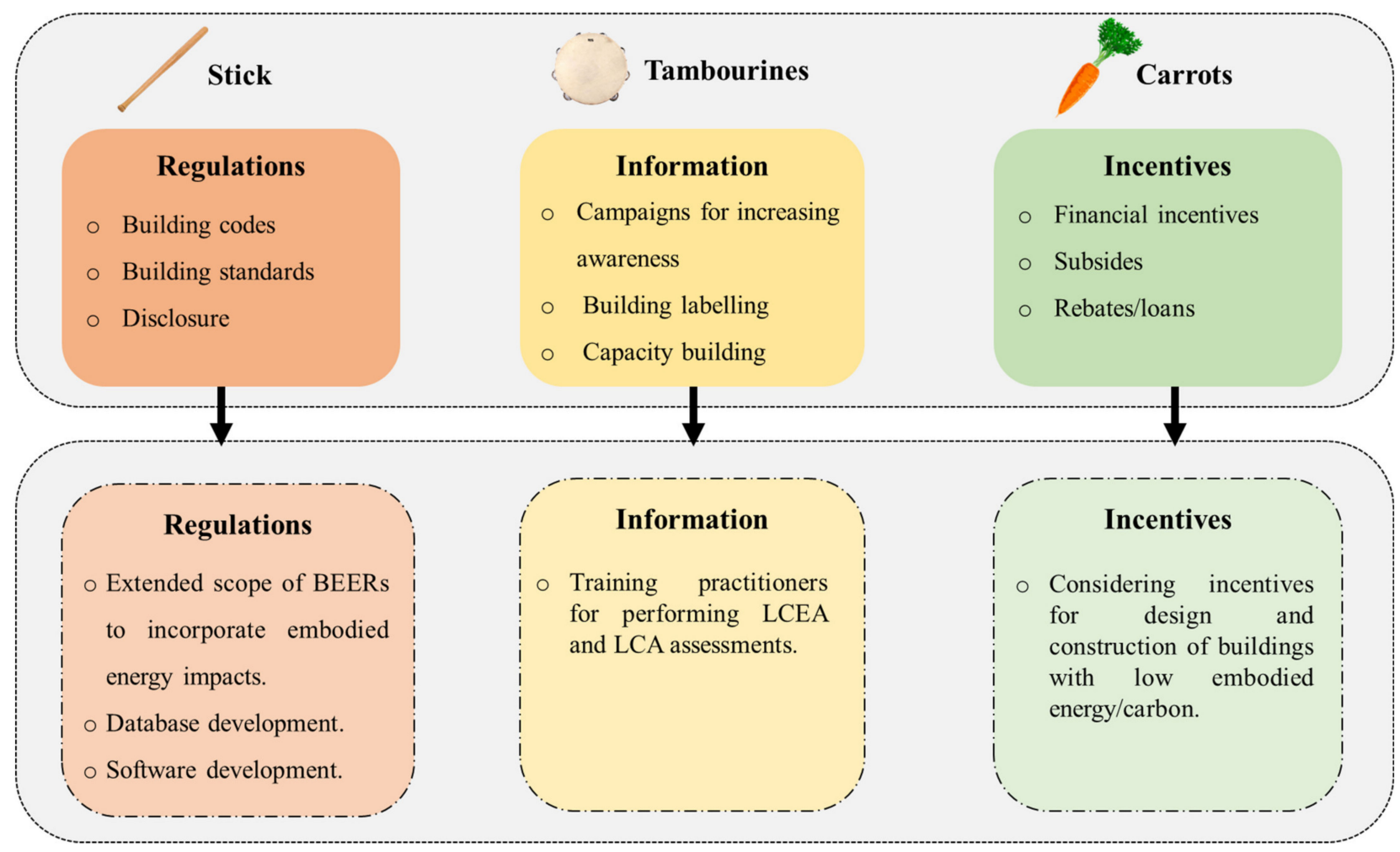

Figure 6. Proposal on further actions for incorporation of embodied energy into BEERs.

Regarding regulations, the scope of current BEERs needs to be extended to include embodied energy. The current scopes of building energy regulations are generally limited to only enhancing the operational energy performance of buildings [45,87]. Hence, the importance of minimising the embodied energy of buildings should be first acknowledged by BEERs and reflected accordingly in the regulatory scheme of building codes. The recommended approach should be accompanied by, first, embodied energy databases to be developed nationally in order to represent the peculiarities of the country, such as economic sectors, construction technologies, manufacturing processes, energy tariffs, and fuel supply structure [23,63]. The Environmental Performance in Construction (EPiC) is an example of such a database that contains the embodied energy coefficients of several building materials in Australia [97]. It is also important that the environmental product declarations (EPDs) [98] for building materials are enforced to provide up-to-date quantified environmental data relating to construction materials. In parallel, investment should be made in developing software with the capacity of pairing with embodied energy databases; thus, designers can readily link their designs with material quantities to carry out embodied energy estimations.

The inclusion of embodied energy into the BEERs will also require launching extensive LCEA or LCA training processes across all professions in the construction industry. This was affirmed by Schwarz et al. [99], who investigated the opinions of building professionals 
on potential challenges to including embodied energy into BEERs. The interviewees pointed out the necessity of initiating LCA learning programs due to the lack of knowledge in the current industry. Lastly, the design and construction of buildings with low embodied energy or embodied carbon performance should be promoted by BEERs through providing different types of incentives. The integrated policies combining the three pillars mentioned above can effectively instigate the promotion of best practice in constructing low life cycle energy buildings in the sector.

\section{Conclusions}

The main motivation for this study was inspired by the continued exclusion of embodied impacts from the frameworks of BEERs in most countries. Despite increasing attention, the pathway for including the impacts of embodied energy into BEERs is still ambiguous. The principal reason for such an ambiguity resides with the complexities that BEERs encounter when accounting for the impacts of both operational and embodied energies due to the various processes and parameters involved. To address this challenge, the development of a comprehensive framework for a clear description of system boundaries can pave the way towards integrating the life cycle embodied environmental impacts into BEERs. Currently, the literature is lacking such a comprehensive framework. Therefore, this paper proposed a comprehensive framework for a clear description of system boundary conditions in LCEA analysis with the aim of promoting the incorporation of embodied energy impacts into BEERs.

The proposed framework was developed based on an extensive literature review analysis of 66 studies representing 243 case studies in over 15 countries. The framework consists of six distinctive dimensions, including temporal, physical, methodological, hypothetical, spatial, and functional. These dimensions encapsulate 15 components collectively. The proposed framework has two key characteristics. First, its application facilitates defining the conditions of a system boundary within a transparent context. This can consequently lead to increasing the reliability of obtained LCEA results for decision-making purposes since any particular condition (e.g., truncation, or assumption) considered in establishing the boundaries of the system under study is revealed. In addition, the use of the proposed framework provides a meaningful basis for cross comparing cases within a global context. This can further result in identifying best practices for the design of buildings with low life cycle energy use performance. In regard to policy making, certain requirements and standards can be set for each dimension of the framework to be practised within a national or regional level. This will provide much better control over standardising the process of including embodied energy into BEERs.

The applicability of the proposed framework was tested by applying the framework to assess the life cycle energy performance of a residential building in Adelaide, Australia. To this end, the framework was first employed to define the system boundary conditions of the case study. It was then utilised to cross compare the obtained results with another case study retrieved from the literature. This cross comparison was carried out to illustrate the capacity of the developed framework for cross comparison. The results of these case studies reaffirm the significance of embodied energy consumption associated with buildings. Results showed that embodied energy constituted 48.2 and $60 \%$ of the total life cycle energy usage for the Adelaide and Melbourne case studies, respectively. These findings underline the urgent demand for incorporation of embodied energy impacts into energy-efficiency building codes. In this regard, the use of the proposed framework contributed to the clear definition of system boundary conditions as well as to providing a standardised basis for cross comparison of cases.

This study also recommends altering the current mindset of policy making in the building sector in order to embrace the addition of embodied energy to BEERs. First, it is recommended that the current scope of BEERs be extended to include the impacts of embodied energy. This inclusion should be accompanied by developing embodied energy databases. It is also recommended that the environmental product declarations 
for building materials should be enforced to provide up-to-date quantified environmental data relating to construction materials. Furthermore, software should be developed with the capacity to pair with embodied energy databases so that designers can readily link their designs with material quantities to perform embodied energy estimations. It is also necessity to launch extensive training processes across all professions in the construction industry in order to increase awareness of LCEA or LCA calculations. In addition, it is recommended that different types of incentives should be allocated in order to promote the design and construction of buildings with low embodied energy or embodied carbon performance. The integrated policies combining the three pillars mentioned above can effectively instigate the promotion of best practices in constructing low life cycle energy buildings in the sector.

Author Contributions: Conceptualization, H.O. and V.S.; methodology, H.O. and V.S.; software, H.O.; writing — original draft preparation, H.O.; writing—review and editing, V.S and J.Z. and R.C.; supervision, V.S. and J.Z. and R.C. All authors have read and agreed to the published version of the manuscript.

Funding: The authors wish to acknowledge the financial support from the Adelaide Scholarship International, Australia (No. ASI-1736049).

Institutional Review Board Statement: Not applicable.

Informed Consent Statement: Not applicable.

Data Availability Statement: Data sharing not applicable.

Conflicts of Interest: The authors declare no conflict of interest.

\section{References}

1. Attia, S. Net Zero Energy Buildings (NZEB): Concepts, Frameworks and Roadmap for Project Analysis and Implementation; ButterworthHeinemann: Oxford, UK, 2018.

2. Omrany, H.; Marsono, A.K. National building regulations of Iran benchmarked with BREEAM and LEED: A comparative analysis for regional adaptations. Curr. J. Appl. Sci. Technol. 2016, 16, 1-15. [CrossRef]

3. Omrany, H.; Ghaffarianhoseini, A.; Ghaffarianhoseini, A.; Raahemifar, K.; Tookey, J. Application of passive wall systems for improving the energy efficiency in buildings: A comprehensive review. Renew. Sustain. Energ. Rev. 2016, 62, 1252-1269. [CrossRef]

4. Satola, D.; Röck, M.; Houlihan-Wiberg, A.; Gustavsen, A. Life Cycle GHG Emissions of Residential Buildings in Humid Subtropical and Tropical Climates: Systematic Review and Analysis. Buildings 2021, 11, 6. [CrossRef]

5. D'Agostino, D.; Mazzarella, L. What is a Nearly zero energy building? Overview, implementation and comparison of definitions. J. Build. Eng. 2019, 21, 200-212. [CrossRef]

6. Chau, C.K.; Leung, T.M.; Ng, W.Y. A review on life cycle assessment, life cycle energy assessment and life cycle carbon emissions assessment on buildings. Appl. Energy 2015, 143, 395-413. [CrossRef]

7. Green Building Council of Australia. Available online: https://new.gbca.org.au/ (accessed on 8 April 2021).

8. Von Bertalanffy, L. General System theory, a new approach to unity of science. 5. Conclusion. Hum. Biol. 1951, 23, 337.

9. Trajectory for Low Energy Buildings. 2019. Available online: http://coagenergycouncil.gov.au/publications/trajectory-lowenergy-buildings (accessed on 20 September 2020).

10. Stephan, A.; Crawford, R.H.; De Myttenaere, K. A comprehensive assessment of the life cycle energy demand of passive houses. Appl. Energy 2013, 112, 23-34. [CrossRef]

11. Crawford, R.H.; Bartak, E.L.; Stephan, A.; Jensen, C.A. Evaluating the life cycle energy benefits of energy efficiency regulations for buildings. Renew. Sustain. Energ. Rev. 2016, 63, 435-451. [CrossRef]

12. Omrany, H.; Soebarto, V.; Ghaffarianhoseini, A. Rethinking the concept of building energy rating system in Australia: A pathway to life-cycle net-zero energy building design. Archit. Sci. Rev. 2021. [CrossRef]

13. Säynäjoki, A.; Heinonen, J.; Junnila, S.; Horvath, A. Can life-cycle assessment produce reliable policy guidelines in the building sector? Environ. Res. Lett. 2017, 12, 013001. [CrossRef]

14. Crawford, R.H. Validation of a hybrid life-cycle inventory analysis method. J. Environ. Manag. 2008, 88, 496-506. [CrossRef]

15. Crawford, R.H. Life Cycle Assessment in the Built Environment; Taylor \& Francis: Abingdon, UK, 2011.

16. Crawford, R.H.; Bontinck, P.A.; Stephan, A.; Wiedmann, T.; Yu, M. Hybrid life cycle inventory methods-A review. J. Clean. Prod. 2018, 172, 1273-1288. [CrossRef]

17. Treloar, G.J. Extracting embodied energy paths from input-output tables: Towards an input-output-based hybrid energy analysis method. Econ. Syst. Res. 1997, 9, 375-391. [CrossRef] 
18. Chan, L.S. Investigating the environmental effectiveness of Overall Thermal Transfer Value code and its implication to energy regulation development. Energy Policy 2019, 130, 172-180. [CrossRef]

19. Davies, P.J.; Emmitt, S.; Firth, S.K. Challenges for capturing and assessing initial embodied energy: A contractor's perspective. Constr. Manag. Econ. 2014, 32, 290-308. [CrossRef]

20. Cavalliere, C.; Habert, G.; Dell'Osso, G.R.; Hollberg, A. Continuous BIM-based assessment of embodied environmental impacts throughout the design process. J. Clean. Prod. 2019, 211, 941-952. [CrossRef]

21. Hollberg, A.; Genova, G.; Habert, G. Evaluation of BIM-based LCA results for building design. Autom. Constr. 2020, $109,102972$. [CrossRef]

22. Moncaster, A.M.; Rasmussen, F.N.; Malmqvist, T.; Wiberg, A.H.; Birgisdottir, H. Widening understanding of low embodied impact buildings: Results and recommendations from 80 multi-national quantitative and qualitative case studies. J. Clean. Prod. 2019, 235, 378-393. [CrossRef]

23. Omrany, H.; Soebarto, V.; Zuo, J.; Sharifi, E.; Chang, R. What leads to variations in the results of life-cycle energy assessment? An evidence-based framework for residential buildings. Energy Built Environ. 2021, 2, 392-405. [CrossRef]

24. Omrany, H.; Soebarto, V.; Sharifi, E.; Soltani, A. Application of Life Cycle Energy Assessment in Residential Buildings: A Critical Review of Recent Trends. Sustainability 2020, 12, 351. [CrossRef]

25. Pan, W.; Li, K.; Teng, Y. Rethinking system boundaries of the life cycle carbon emissions of buildings. Renew. Sustain. Energy Rev. 2018, 90, 379-390. [CrossRef]

26. Pan, W.; Teng, Y. A systematic investigation into the methodological variables of embodied carbon assessment of buildings. Renew. Sustain. Energy Rev. 2021, 141, 110840. [CrossRef]

27. Dixit, M.K. Life cycle embodied energy analysis of residential buildings: A review of literature to investigate embodied energy parameters. Renew. Sustain. Energy Rev. 2017, 79, 390-413. [CrossRef]

28. Dixit, M.K.; Culp, C.H.; Fernández-Solís, J.L. System boundary for embodied energy in buildings: A conceptual model for definition. Renew. Sustain. Energy Rev. 2013, 21, 153-164. [CrossRef]

29. Moncaster, A.M.; Pomponi, F.; Symons, K.E.; Guthrie, P.M. Why method matters: Temporal, spatial and physical variations in LCA and their impact on choice of structural system. Energy Build. 2018, 173, 389-398. [CrossRef]

30. International Organization for Standardization. Environmental Management: Life Cycle Assessment; Principles and Framework (No. 2006); International Organization for Standardization: Geneva, Switzerland, 2006.

31. EN 15978. CEN-European Committee for Standardization. Sustainability of Construction Works-Assessment of Environmental Performance of Buildings_Calculation Method; European Committee for Standardization: Brussels, Belgium, 2011.

32. Karimpour, M.; Belusko, M.; Xing, K.; Bruno, F. Minimising the life cycle energy of buildings: Review and analysis. Build. Environ. 2014, 73, 106-114. [CrossRef]

33. ISO (International Organization for Standardization). Environmental Management-Life Cycle Assessment-Requirements and Guidelines; International Organization for Standardization: Geneva, Switzerland, 2006.

34. Luhmann, N. System as difference. Organization 2006, 13, 37-57. [CrossRef]

35. Deng, S.; Wang, R.Z.; Dai, Y.J. How to evaluate performance of net zero energy building-A literature research. Energy 2014, 71, 1-16. [CrossRef]

36. Marique, A.F.; Reiter, S. A simplified framework to assess the feasibility of zero-energy at the neighbourhood/community scale. Energy Build. 2014, 82, 114-122. [CrossRef]

37. Pan, W. System boundaries of zero carbon buildings. Renew. Sustain. Energy Rev. 2014, 37, 424-434. [CrossRef]

38. Giordano, R.; Serra, V.; Tortalla, E.; Valentini, V.; Aghemo, C. Embodied energy and operational energy assessment in the framework of nearly zero energy building and building energy rating. Energy Procedia 2015, 78, 3204-3209. [CrossRef]

39. Stephan, A.; Crawford, R.H.; De Myttenaere, K. Towards a comprehensive life cycle energy analysis framework for residential buildings. Energy Build. 2012, 55, 592-600. [CrossRef]

40. Sartori, I.; Hestnes, A.G. Energy use in the life cycle of conventional and low-energy buildings: A review article. Energy Build. 2007, 39, 249-257. [CrossRef]

41. Hammond, G.P.; Jones, C.I. Embodied carbon: The concealed impact of residential construction. In Global Warming; Springer: Boston, MA, USA, 2010; pp. 367-384. [CrossRef]

42. Fay, M.R. Comparative Life Cycle Energy Studies of Typical Australian Suburban Dwellings. Ph.D. Thesis, University of Melbourne, Australia, 1999.

43. Herendeen, R. Embodied Energy, Embodied Everything ... Now What? Advances in Energy Studies. Energy Flows in Ecology and Economy; VI European Week of Scientific Culture; Musis Publisher: Roma, Italy, 1988; pp. 13-48.

44. Pan, W. A Decision Support Tool for Optimising the Use of Offsite Technologies in Housebuilding. Ph.D. Thesis, Loughborough University, Loughborough, UK, 2011.

45. Pomponi, F.; Moncaster, A. Scrutinising embodied carbon in buildings: The next performance gap made manifest. Renew. Sustain. Energy Rev. 2018, 81, 2431-2442. [CrossRef]

46. Srinagesh, K. The Principles of Experimental Research; Butterworth-Heinemann: Oxford, UK, 2006.

47. Bhattacherjee, A. Social science research: Principles, methods, and practices. In Global Text Project; University of South Florida: Tampa, FL, USA, 2012.

48. DesignBuilder. EnergyPlus Simulation. Available online: https:/ / designbuilder.co.uk/simulation (accessed on 3 May 2020). 
49. Pullen, S.F. The Spatial Representation of Embodied Energy of Residential Areas in the Urban Environment. Ph.D. Thesis, University of South Australia, Australia, 2008.

50. Crawford, R.H. Post-occupancy life cycle energy assessment of a residential building in Australia. Archit. Sci. Rev. 2014, 57, 114-124. [CrossRef]

51. Khasreen, M.M.; Banfill, P.F.; Menzies, G.F. Life-cycle assessment and the environmental impact of buildings: A review. Sustainability 2009, 1, 674-701. [CrossRef]

52. Ramesh, T.; Prakash, R.; Shukla, K.K. Life cycle energy analysis of buildings: An overview. Energy Build. 2010, 42, 1592-1600. [CrossRef]

53. Chastas, P.; Theodosiou, T.; Bikas, D. Embodied energy in residential buildings-towards the nearly zero energy building: A literature review. Build. Environ. 2016, 105, 267-282. [CrossRef]

54. Röck, M.; Saade, M.R.M.; Balouktsi, M.; Rasmussen, F.N.; Birgisdottir, H.; Frischknecht, R.; Habert, G.; Lützkendorf, T.; Passer, A. Embodied GHG emissions of buildings-The hidden challenge for effective climate change mitigation. Appl. Energy 2020, 258, 114107. [CrossRef]

55. Yung, P.; Lam, K.C.; Yu, C. An audit of life cycle energy analyses of buildings. Habitat Int. 2013, 39, 43-54. [CrossRef]

56. Wong, J.H.; Royapoor, M.; Chan, C.W. Review of life cycle analyses and embodied energy requirements of single-crystalline and multi-crystalline silicon photovoltaic systems. Renew. Sustain. Energy Rev. 2016, 58, 608-618. [CrossRef]

57. Crawford, R.H. Life cycle energy and greenhouse emissions analysis of wind turbines and the effect of size on energy yield. Renew. Sustain. Energy Rev. 2009, 13, 2653-2660. [CrossRef]

58. Stephan, A.; Stephan, L. Reducing the total life cycle energy demand of recent residential buildings in Lebanon. Energy 2014, 74, 618-637. [CrossRef]

59. Bastos, J.; Batterman, S.A.; Freire, F. Significance of mobility in the life-cycle assessment of buildings. Build. Res. Inf. 2016, 44, 376-393. [CrossRef]

60. Treloar, G.; Fay, R.; Love, P.E.D.; Iyer-Raniga, U. Analysing the life-cycle energy of an Australian residential building and its householders. Build. Res. Inf. 2000, 28, 184-195. [CrossRef]

61. Yang, Y. Does hybrid LCA with a complete system boundary yield adequate results for product promotion? Int. J. Life Cycle Assess. 2017, 22, 456-460. [CrossRef]

62. Kristjansdottir, T.F.; Houlihan-Wiberg, A.; Andresen, I.; Georges, L.; Heeren, N.; Good, C.S.; Brattebø, H. Is a net life cycle balance for energy and materials achievable for a zero emission single-family building in Norway? Energy Build. 2018, 168, 457-469. [CrossRef]

63. Dixit, M.K.; Fernández-Solís, J.L.; Lavy, S.; Culp, C.H. Identification of parameters for embodied energy measurement: A literature review. Energy Build. 2010, 42, 1238-1247. [CrossRef]

64. Stephan, A.; Crawford, R.H. The relationship between house size and life cycle energy demand: Implications for energy efficiency regulations for buildings. Energy 2016, 116, 1158-1171. [CrossRef]

65. de Simone Souza, H.H.; de Abreu Evangelista, P.P.; Medeiros, D.L.; Albertí, J.; Fullana-i-Palmer, P.; Boncz, M.Á.; Kiperstok, A.; Gonçalves, J.P. Functional unit influence on building life cycle assessment. Int. J. Life Cycle Assess. 2021, 26, 1-20. [CrossRef]

66. Gustavsson, L.; Joelsson, A. Life cycle primary energy analysis of residential buildings. Energy Build. 2010, 42, 210-220. [CrossRef]

67. Ghaffarianhoseini, A.; Ghaffarianhoseini, A.; Tookey, J.; Omrany, H.; Fleury, A.; Naismith, N.; Ghaffarianhoseini, M. The essence of smart homes: Application of intelligent technologies towards smarter urban future. In Artificial Intelligence: Concepts, Methodologies, Tools, and Applications; IGI Global: Hershey, PA, USA, 2017; pp. 79-121. [CrossRef]

68. Devi, P.; Palaniappan, S. A case study on life cycle energy use of residential building in Southern India. Energy Build. 2014, 80, 247-259. [CrossRef]

69. Karimpour, M.; Belusko, M.; Xing, K.; Boland, J.; Bruno, F. Impact of climate change on the design of energy efficient residential building envelopes. Energy Build. 2015, 87, 142-154. [CrossRef]

70. Gustavsson, L.; Joelsson, A.; Sathre, R. Life cycle primary energy use and carbon emission of an eight-storey wood-framed apartment building. Energy Build. 2010, 42, 230-242. [CrossRef]

71. Peel, M.C.; Finlayson, B.L.; McMahon, T.A. Updated world map of the Köppen-Geiger climate classification. Hydrol. Earth Syst. Sci. 2007, 11, 1633-1644. [CrossRef]

72. Jan, T.S.; Liu, M.W.; Kao, Y.C. An upper-bound pushover analysis procedure for estimating the seismic demands of high-rise buildings. Eng. Struct. 2004, 26, 117-128. [CrossRef]

73. Wang, J.; Yu, C.; Pan, W. Life cycle energy of high-rise office buildings in Hong Kong. Energy Build. 2018, 167, 152-164. [CrossRef]

74. Du, P.; Wood, A.; Stephens, B.; Song, X. Life-cycle energy implications of downtown high-rise vs. suburban low-rise living: An overview and quantitative case study for Chicago. Buildings 2015, 5, 1003-1024. [CrossRef]

75. Treloar, G.J.; Fay, R.; Ilozor, B.; Love, P.E. An analysis of the embodied energy of office buildings by height. Facilities 2001, 19, 204-214. [CrossRef]

76. Winistorfer, P.; Chen, Z.; Lippke, B.; Stevens, N. Energy consumption and greenhouse gas emissions related to the use, maintenance, and disposal of a residential structure. Wood Fiber Sci. 2007, 37, 128-139.

77. Crowther, P. Design for disassembly to recover embodied energy. In Proceedings of the Sustaining the Future: Energy Ecology Architecture PLEA'99, Brisbane, Australia, 22-24 September 1999; pp. 95-100.

78. Dixit, M.K. Life cycle recurrent embodied energy calculation of buildings: A review. J. Clean. Prod. 2019, 209, 731-754. [CrossRef] 
79. Cabeza, L.F.; Rincón, L.; Vilariño, V.; Pérez, G.; Castell, A. Life cycle assessment (LCA) and life cycle energy analysis (LCEA) of buildings and the building sector: A review. Renew. Sustain. Energy Rev. 2014, 29, 394-416. [CrossRef]

80. Australian Gas Networks-South Australia. Available online: https://www.australiangasnetworks.com.au/gas-explained/aboutnatural-gas / costs-of-natural-gas\#: \{\}:text=An \%20average $\% 20$ Adelaide $\% 20$ home $\% 20$ with, saving\%20of $\% 20 \% 24727 \% 20$ per $\%$ 20year (accessed on 29 October 2020).

81. Australian Government Bureau of Meteorology. Available online: http://www.bom.gov.au/climate/data-services/solarinformation.shtml (accessed on 16 August 2020).

82. ASHRAE; USGBC. Standard 189.1-2011-Standard for the Design of High-Performance Green Buildings; American Society of Heating, Refrigerating and Air-Conditioning Engineers: Atlanta, GA, USA; U.S. Green Building Council: Washington, DC, USA, 2011.

83. NCC, National Constructions Code. Guide to Volume Two. Section J-Energy Efficiency. 2019. Available online: https://ncc.abcb. gov.au/ncc-online/ncc (accessed on 25 October 2020).

84. Daniel, L.; Williamson, T.; Soebarto, V. Comfort-based performance assessment methodology for low energy residential buildings in Australia. Build. Environ. 2017, 111, 169-179. [CrossRef]

85. Daniel, L.; Soebarto, V.; Williamson, T. House energy rating schemes and low energy dwellings: The impact of occupant behaviours in Australia. Energy Build. 2015, 88, 34-44. [CrossRef]

86. Van Dronkelaar, C.; Dowson, M.; Burman, E.; Spataru, C.; Mumovic, D. A review of the energy performance gap and its underlying causes in non-domestic buildings. Front. Mech. Eng. 2016, 1, 17. [CrossRef]

87. De Wolf, C.; Pomponi, F.; Moncaster, A. Measuring embodied carbon dioxide equivalent of buildings: A review and critique of current industry practice. Build. Environ. 2017, 140, 68-80. [CrossRef]

88. Scholten, N.P.; van Ewijk, H.A. Environmental performance regulations in the Netherlands. In Proceedings of the 4th International Conference CIVIL ENGINEERING'13 Proceedings Part I: BUILDING AND RENOVATION, Jelgava, Latvia, 16-17 May 2013; p. 245.

89. Kuittinen, M.; le Roux, S. Procurement Criteria for Low-Carbon Building; Ministry of the Environment: Helsinki, Finland, 2018.

90. Norwegian Standard NS 3720: 2018 Method for Greenhouse Gas Calculations for Buildings; Standard Norge: Oslo, Norway, 1 September 2018.

91. Frivillig Baeredygtighetsklasse i Bygningsreglementet. Oplaeg fra Byggebranchen. InnoBYG. 2018. Available online: https:// www.innobyg.dk/om-innobyg/publikationer/frivillig-baeredygtighedsklasse-i-bygningsreglementet/ (accessed on 19 August 2020).

92. The Danish Government. Strategy for the Circular Economy; The Danish Government: Copenhagen, Denmark, 2018.

93. Birgisdottir, H.; Moncaster, A.; Wiberg, A.H.; Chae, C.; Yokoyama, K.; Balouktsi, M.; Seo, S.; Oka, T.; Lützkendorf, T.; Malmqvist, T. IEA EBC annex 57 'evaluation of embodied energy and CO2eq for building construction'. Energy Build. 2017, 154, 72-80. [CrossRef]

94. Fufa, S.M.; Schlanbusch, R.D.; Sørnes, K.; Inman, M.R.; Andresen, I. A Norwegian ZEB Definition Guideline; SINTEF Academic Press: Trondheim, Norway, 2016.

95. Azevedo, I.; Delarue, E.; Meeus, L. Mobilizing cities towards a low-carbon future: Tambourines, carrots and sticks. Energy Policy 2013, 61, 894-900. [CrossRef]

96. Hu, S.; Yan, D.; Azar, E.; Guo, F. A systematic review of occupant behavior in building energy policy. Build. Environ. 2020, 175, 106807. [CrossRef]

97. Crawford, R.; Stephan, A.; Prideaux, F.; Bontinck, P.A. Environmental performance in construction (EPiC). 2020. Available online: https://www.researchgate.net/profile/Andre-Stephan/publication/337730690_Environmental_Performance_ in_Construction_EPiC_Database/links/5e5cfd67a6fdccbeba12cb87/Environmental-Performance-in-Construction-EPiCDatabase.pdf (accessed on 26 March 2021).

98. International Standard 14025/TR: Environmental Labels and Declarations-Type III Environmental Declarations-Principles and Procedures; International Organization for Standardization (ISO): Geneva, Switzerland, 2006.

99. Schwarz, M.; Nakhle, C.; Knoeri, C. Innovative designs of building energy codes for building decarbonization and their implementation challenges. J. Clean. Prod. 2020, 248, 119260. [CrossRef] 